WESTINGHOUSE SAVANNAH RIVER COMPANY

ENGINGEERIVG AVU PRUIL TSUIVISIO

SYSTEMS EVUIVLLIINC

EWR NO. 866422
WSRC-TR- $-91-473$

DE92. C15123

KEY WORDS: Response Spectra

SASSI

K-Reactor

Seismic

RETENTION PERIOD: LIFETIME

\title{
IMPACT OF NEW K AREA GEOTECHNICAL PARAMETERS ON K REACTOR RESTART RESTPONSE SPECTRA (U)
}

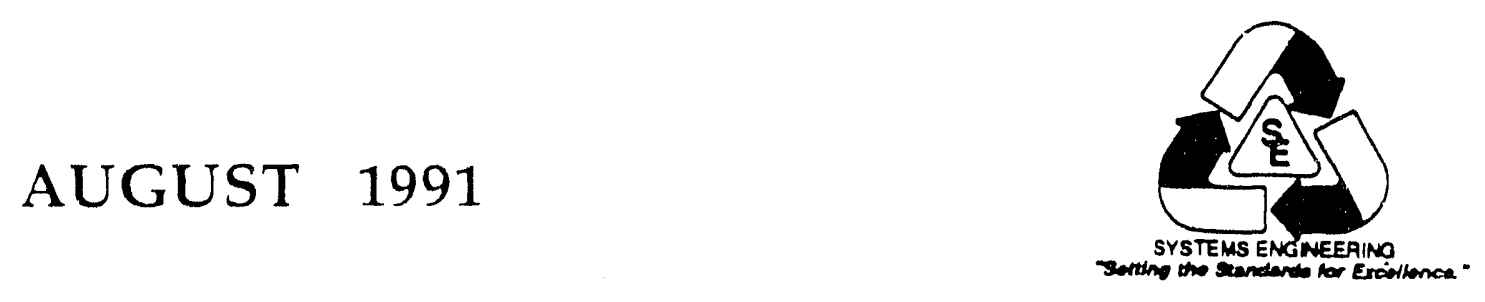

SEISMIC STRUCTURAL ENGINEERING

\author{
DISCLAIMER
}

This repoic was prepared as an account of work sponsored by an agency of the United States Government. Neither the United States Government nor any agency thereof, nor any of their employees, makes any warranty, express or implied, or assumes any legal liability or responsibility for the accuracy, completeness, or usefulness of any information, apparatus, product, or process disclosed, or represents that its use would not infringe privately owned rights. Reference herein to any specific commercial product, process, or service by trade name, trademark, manufacturer, or otherwise does not necessarily constitute or imply its endorsement, recommendation, or favoring by the United States Government or any agency thereof. The views and opinions of authors expressed herein do not necessarily state or reflect those of the United States Government or any agency thereof. 
WESTINGHOUSE SAVANNAH RIVER COMPANY

ENGINEERING AND PROJECTS DIVISION

WSRC-TR-91-473

SYSTEIIS ENGINEERING

EWR NO. 866422

\section{IMPACT OF NEW K-AREA GEOTECHNICAL PARAMETERS ON K-REACTOR RESTART RESPONSE SPECTRA (U)}

\section{AUGUST 1991}

PREPARED

PREPARED

PREPARED

J. A. Amin

Seismic Structural Engineering

APPROVED

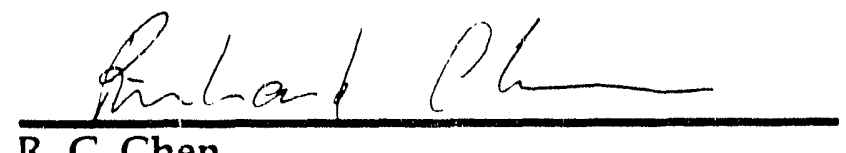

R. C. Chen

Seismic Structural Engineering

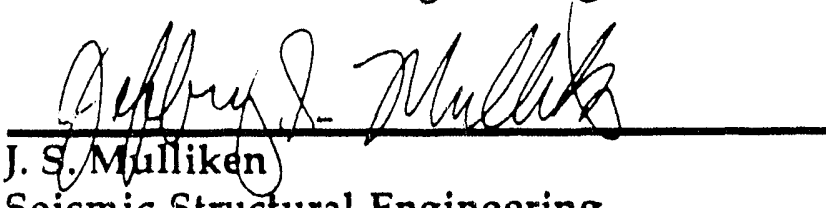

Seismic Structural Engineering

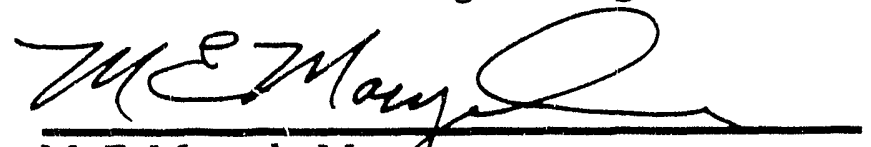

M. E. Maryak, Manager

Seismic StructurafEngineering

\section{APPROVED}

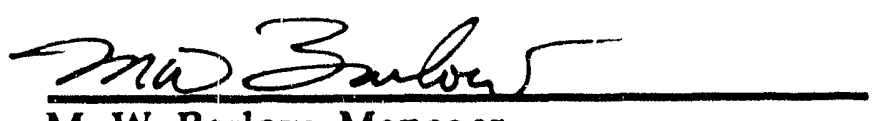

M. W. Barlow, Manager

Seismic Engineering 
WESTINGHOUSE SAVANNAH RIVER COMPANY

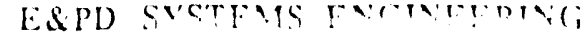

SEISUIC , HLL

K-REACTOR SOIL PROFILE STUDY
WSRC-TR-91 $1+473$

REIISION 0

ALGLST, 1991

PAGE I OF i

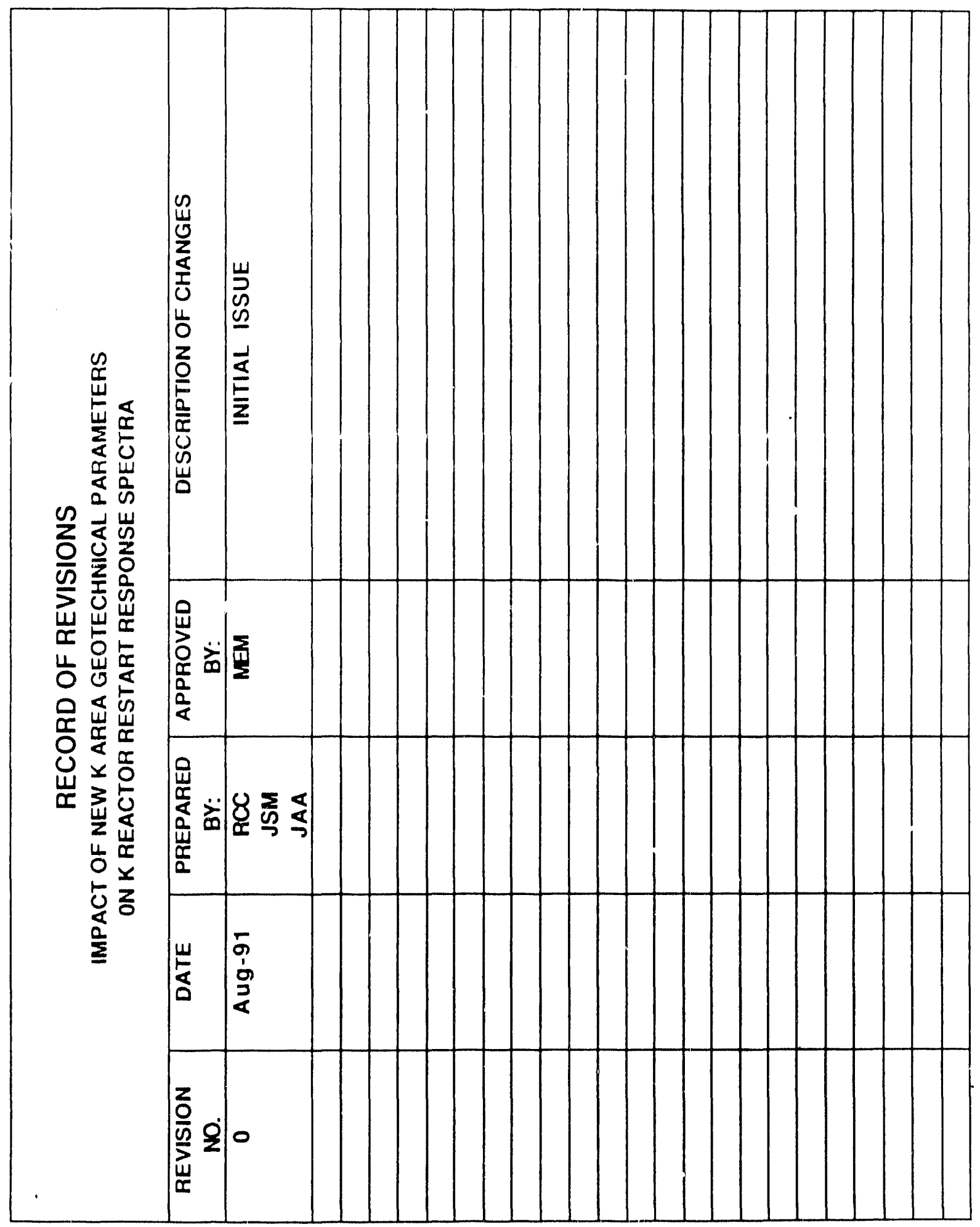




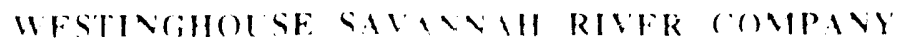

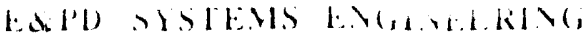

WSR(-IR.91-7.3

RIISIO) I

SEISMIC STRUCTURAI ENGINEERING;

AlicsT, 1091

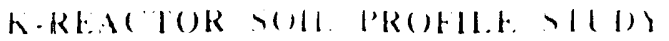

P'Alit, I w i

\section{TABLE OF CONTENTS}

ITEM

PAGE

1.0 Introduction

2

2.0 Study Procedure 2

2.1 Review of Existing Reactor Analysis 2

2.2 Model Modification 3

2.3 Live Loads 4

2.4 Proposed Soil Profiles +

2.5 Strain Dependent Curves 5

2.6 Time History 5

2.7 Seismic Evaluation 5

2.8 Stack Building Impact 6

$\begin{array}{ll}3.0 & \text { Conclusion }\end{array}$

References

Tables T1 to T4

$\begin{array}{ll}\text { Figures } & \text { F1 to F31 }\end{array}$ 


\section{I.O INTRODUCTION}

This report provides a description of a study performed to evaluate the impact of recently obtained soils parameters on the 105-K Reactor using Soil-Structure Interaction (SSI) analysis. New soils data provided for KArea resulted from an extensive geotechnical investigation and was reported in Reference 1.

This study includes:

- The frequency check of the reactor building based on the fixed base analysis.

- The modification of the computer model to reflect actual building properties and building frequencies.

- The live luad impact un seismic analysis.

- The comparison of soil spectrum at elev. $-50 \mathrm{ft}$ with $60 \%$ of RG1.60 curve.

- Comparison of spectral results to the previous FREDA and SASSI results

- Implications to the stack building analysis.

\subsection{STUDY PROCEDURE}

\subsection{RFVIEW OF EXISTING K REACTOR ANALYSIS}

The K-Reactor Building seismic analysis was performed by URS/Blume (2) in August, 1989. Using then available soil data, Blume generated floor acceleration response spectra(FRS) for use in qualifying equipment for the Interim Seismic Program. URS/Blume's proprietary computer code FREDA(3) was used to compute the soil-structure-interaction (SSI) response of the building. FREDA performs a frequency domain analysis to compute the SSI response. 
A parametric study using the SASSI $(4)$ computer code was also performed by URS/Blume to examine conservatisms provided in the FREDA computations. The URS/Blume SASSI model was developed specifically to provide best estimate results and represent the FREDA model as closely as possible. This structural model consists of rigid, massless eight node brick elements to represent the embedded outer walls and the foundation. The base of the structural model represents a doubly symmetric structure embedded in the soil down to elevation $-50 \mathrm{ft}$. The reactor building superstructure is the lumped-mass stick model utilized in the FREDA analysis and was attached to the wall-foundation elements by rigid beams at the $-20^{\prime}$ elevation which transfer soil motion to the stick. FRS was generated with SASSI for the North-South direction at 5\% damping and compared with the FRS generated by FREDA. The structural frequencies and modal participation factors are also generated.

\subsection{MODEL. MODIFICATION}

To incorporate building properties at elevation $.50 \mathrm{ft}$, the Seismic Engineering Group modified the URS/Blume model to add a vertical beam element which extends from elevation $-20 \mathrm{ft}$ to $-50 \mathrm{ft}$ with verified building properties. The revised stick model representing the reactor building is connected to the below grade structural shell by two horizontal beams running in the direction of input motion, one at elevation $-20 \mathrm{ft}$, another at elevation $0 \mathrm{ft}$. Both horizontal beams are provided to simulate actual structural diaphragm action below grade. The masses in the modified model are lumped to the respective nodes at appropriate elevations to more accurately represent the structure. The structural frequencies of the modilied model approximately match the frequencies shown in the URS/Blume Report.(Table 1) 
To appropriately adjust the mass lumped at elevation -20 feet from the FREDA model, the actual weight of the structure at elevation -20 feet and at elevation -40 feet was calculated. The weight of twelve heat exchangers (250 KIP each) were added to the mass lumped at elevation - 20 feet. The resulting weight at elevation -20 feet is 67,116 KIPs and the weight at elevation -50 feet is 105,074 KIPs. For comparative purposes, the participating live load at -20 was calculated to determine the relative magnitude and impact. A live load of 20 pounds per square foot, which makes up a total $\left(20\right.$ psf $\left.\times 220^{\prime} \times 200^{\prime}\right)=880 \mathrm{KIPs}$ at elevation -20 feet, will represent $1.3 \%$ of the lumped mass at that level. Based on this comparison, the live load will have a negligible effect on seismic analysis utilizing a lumped mass concentric stick model.

\subsection{PROPUSED SOIL PRUR-ILES}

The proposed best estimate soil profile is based on the weighted average of GEI soil data from crossholes $\mathrm{K}-1008$ and $\mathrm{K}-1012$. In general, the factor for lower bound shear modulus is 0.5 times the best estimate and the factor for upper bound shear modulus is 2.0 times the best estimate. The lower bound was expanded at three points to cover data that was lying outside of the conservative lower bounding of 0.5 (Fig. 1). The SHAKE (4) computer code was used to generate best estimate, lower bound and upper bound soil spectra at elevation -50 feet, winich is the basemat level of the structure. The enveloped free field soil response at -50 feet (Fig. 2) envelopes the $60 \%$ Regulatory Guide 1.60 target spectrum at all frequencies in accordance with the Standard Review Plan. An acceleration profile with depth for free field analysis was also generated for each soil condition. (Fig. 3) A curve of the effective strains with depth for free field analysis is also generated. (Fig. 7)

The SHAKE input has the same layering as that of SASSI. The iterated values of shear moduli from SHAKE were converted to shear wave velocities and $\mathrm{P}$ wave velocities and then entered into SASSI input files. (Tables 3\&4) 


\subsection{STRAIN DEPENDENT CURVES}

The proposed site specific shear modulus and damping vs shear strain curves (Fig. 4) by GEI, were utilized for this analysis. The original URS/Blume analysis utilized the standard Seed and Idriss curves for sandy soils.

\subsection{TIME HISTORY}

The same time history which was used in URS/Blume SASSI analysis was used for both north-south and east-west directions.(Ref. 2)

\subsection{SEISMIC EVALUATION}

The Seismic Engineering Group evaluated three soil conditions (lower bound, best estimate and upper bound) for both east-west and north-south directions to determine the effects on seismic analysis due to the proposed soil profiles. Two soil models are generated for the six SASSI runs. The first model which was used for the best estimate and upper bound conditions utilizes the same layering as that by URS/Blume. The second model, for the lower bound condition, has a modified layering arrangement to allow passage of higher frequencies. The top $50 \mathrm{ft}$ soil for the lower bound model (Fig. 5) is divided into five $10 \mathrm{ft}$ layers compared to two $10 \mathrm{ft}$ layers and two $15 \mathrm{ft}$ layers as used in the URS/Blume model and this study's best estimate and upper bound model. This change is to better capture the frequency of the analysis for the lower bound soil condition.

Floor response spectra (FRS) for each soil condition and each node with lumped mass were generated and compared to the enveloped FREDA spectrum. (Fig 8 to Fig 31) The FRS at every elevation below 91 feet for all six conditions are lower than the respective FREDA spectra from SEP11. Some excursions of broadened spectra occurred at higher elevations in the north-south direction only. For elevations at or above 91 feet, every point of the enveloped raw SASSI spectra is lower than FREDA spectra, but one point of the broadened spectra from SASSI is outside of FREDA spectra into the lower frequency range. These minor excursions are also shown in the URS/Blume SASSI parametric study. There is no impact to any restart analysis due this small excursion. 


\subsection{STACK BUILDING IMPAC'T}

To assess the impact of the new soils profile on the stack building, a comparison of ZPA's for the old best estimate and new best estimate soil condition using the reactor stick model was made (see Table 2). It can be seen that little difference occurs in the lower elevations but the ZPA's increase in the upper elevations. An attempt was made to evaluate this change in response, but the review proved inconclusive, due to the many variables involved in the comparison. Those variables included damping differences, strain independent functions, building to building interactions, structural frequencies, etc.

In attempting correlation, it became evident that the final results would be inconclusive, but not necessarily cause concerns for overall structural integrity. Based on this, a reevaluation would not be urgently needed considering the newly strengthened structure. This reevaluation is to be structured as a SEP. An SEP approach is appropriate based on the structures importance to shutdown in a post seismic event (ie. contains no safe shutdown equipment). The only significant piece of equipment contained in this structure is the confinement filter, an accident mitigation system, not required for restart. These filters are presently being redesigned to a very conservative spectra. (See Figures 6-1,6-2 \& 6-3) Based on the above, this new analysis will be aggressively pursued as a post restart activity. 


\subsection{CONCLUSION}

The conclusions of Seismic Engineering Group's study based on new proposed soil profile are:

1) The FRS at every elevation below 91 feet for all six conditions are lower than the respective FREDA spectra used for restart analysis. Therefore, there is no impact on any $\mathrm{K}$-reactor restart analysis.

2) The zero period accelerations (ZPA) at all elevations are lower than the FREDA ZPA's, thus the structural evaluation based on the FREDA is still valid and provides a conservative loading.

3) The impact of new soils on the stack building is inconclusive, but based on recent upgrades and importance to safe shut down, it will be reevaluated in a post restart SEP program.

Based on the reviews, the complexity of the reactor and stack building is apparent and continued assessment is warranted for the long term seismic improvement program. 


\section{REFERENCE}

1) K-Reactor Area Geotechrical investigation for seismic issues, Savannah River Site (U), March 1991,WSRC Seismic Structural Engineering.

2) Floor Acceleration Response Spectra for Updated DBE \& Reg. Guide 1.60 Seismic Input: Building 105-K, Savannah River Plant, Aug 1989. URS/John A. Blume \& Associates, engineering.

3) FREDA: FREquency Domain Analysis, URS/John A. Blume \& Associates, Engineering.

4) SASSI: A S System for A Analysis of Soil Structure Interaction, July 1988 Bechtel Power Corporation. 
WESTINGHOUSE SAVANNAH RIVER COMPANY FRPD SYSTFMS FVOIVERIVG;

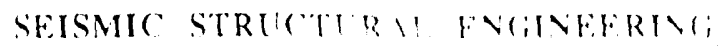

K-REACTOR SOIL PROFILE STUUY
WSRC-TR-91-473

REVISION O

Al(iLST, 1991

\section{TABLES}


WESTINGHOUSE SAVANNAH RIVER COMPANY

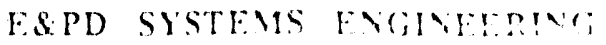

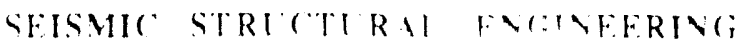

K-REACTOR SOIL PROFILE STULY
WSKC:TR-91-473

REVISION ()

H(ifilsi, 1991

PAGE T1 OF Tt

\section{NORTH-SOUTH DIRECTION}

\begin{tabular}{|c|c|c|}
\hline \multirow{2}{*}{$\begin{array}{c}\text { MODE } \\
\text { NO. }\end{array}$} & \multicolumn{2}{|c|}{ FREQUENCY (HZ) } \\
\cline { 2 - 3 } & FIXED @ -20 & SASSI \\
\hline 1 & 6.93 & 7.05 \\
2 & 12.47 & 12.84 \\
3 & 19.71 & 20.98 \\
4 & 24.57 & 25.55 \\
5 & 31.76 & 33.97 \\
\hline
\end{tabular}

\section{EAST-WEST DIRECTION}

\begin{tabular}{|c|c|c|}
\hline \multirow{2}{*}{$\begin{array}{c}\text { MODE } \\
\text { NO. }\end{array}$} & \multicolumn{2}{|c|}{ FREQUENCY $(\mathrm{HZ})$} \\
\cline { 2 - 3 } 1 & FIXED @ -20 & SASSI \\
\hline & 9.53 & 9.89 \\
2 & 13.85 & 14.79 \\
3 & 22.16 & 23.07 \\
4 & 28.04 & 31.95 \\
5 & 36.75 & 38.43 \\
\hline
\end{tabular}

TABLE 1: STRUCTURAL FREQUENCIES OF THE FREDA MODEL AND THE MODIFIED SASSI MODEL 
WESTINGHOUSE SAVANNAH RIVER COMPANY

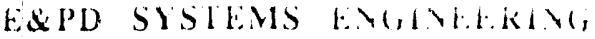

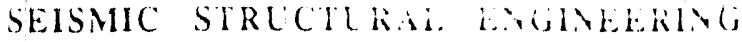

K-REACTOR SOIL PROFILE STUDY
WS R C - TR R $91 \cdot+73$

RLVISIO): 0

Aliust, 1991

PAGE T2 OF TA

NORTH-SOUTH DIRECTION

BEST ESTIMATE SOILS

\begin{tabular}{|c|c|c|}
\hline \multirow{2}{*}{$\begin{array}{l}\text { ELEV. } \\
\text { (FEET) }\end{array}$} & \multicolumn{2}{|c|}{ ACCELERATION (G) } \\
\hline & GEI & BLUME \\
\hline 148.67 & 0.61 & 0.48 \\
\hline 130 & 0.51 & 0.44 \\
\hline 125 & 0.48 & 0.41 \\
\hline 120 & 0.45 & 0.38 \\
\hline 110 & 0.40 & 0.34 \\
\hline 91.25 & 0.29 & 0.25 \\
\hline 66 & 0.22 & 0.20 \\
\hline 48 & 0.21 & 0.19 \\
\hline 34 & 0.19 & 0.18 \\
\hline 15 & 0.18 & 0.17 \\
\hline 0 & 0.17 & 0.17 \\
\hline-20 & $\$ .17$ & 0.16 \\
\hline
\end{tabular}

TABLE 2: SEISMIC PEAK ACCELERATIONS AT DIFFERENT ELEVATIONS FROM SASSI ANALYSES WITH BLUME SOIL PROFILE AND NEW PROPOSED SOIL PROFILE FROM GEI DATA 
WESTINGHOUSE SAVAVVAH RIVER COMPINY

E\&PD SYSTEMS ENGINFFRING;

SEISMIC STRUCTURAL ENGINEERING

K-REACTOR SOIL PROFIIE STUDY
WSRC-TR-91+473

RISISIOY O

AUGUST, 1991

PAC TE T3 OF TA

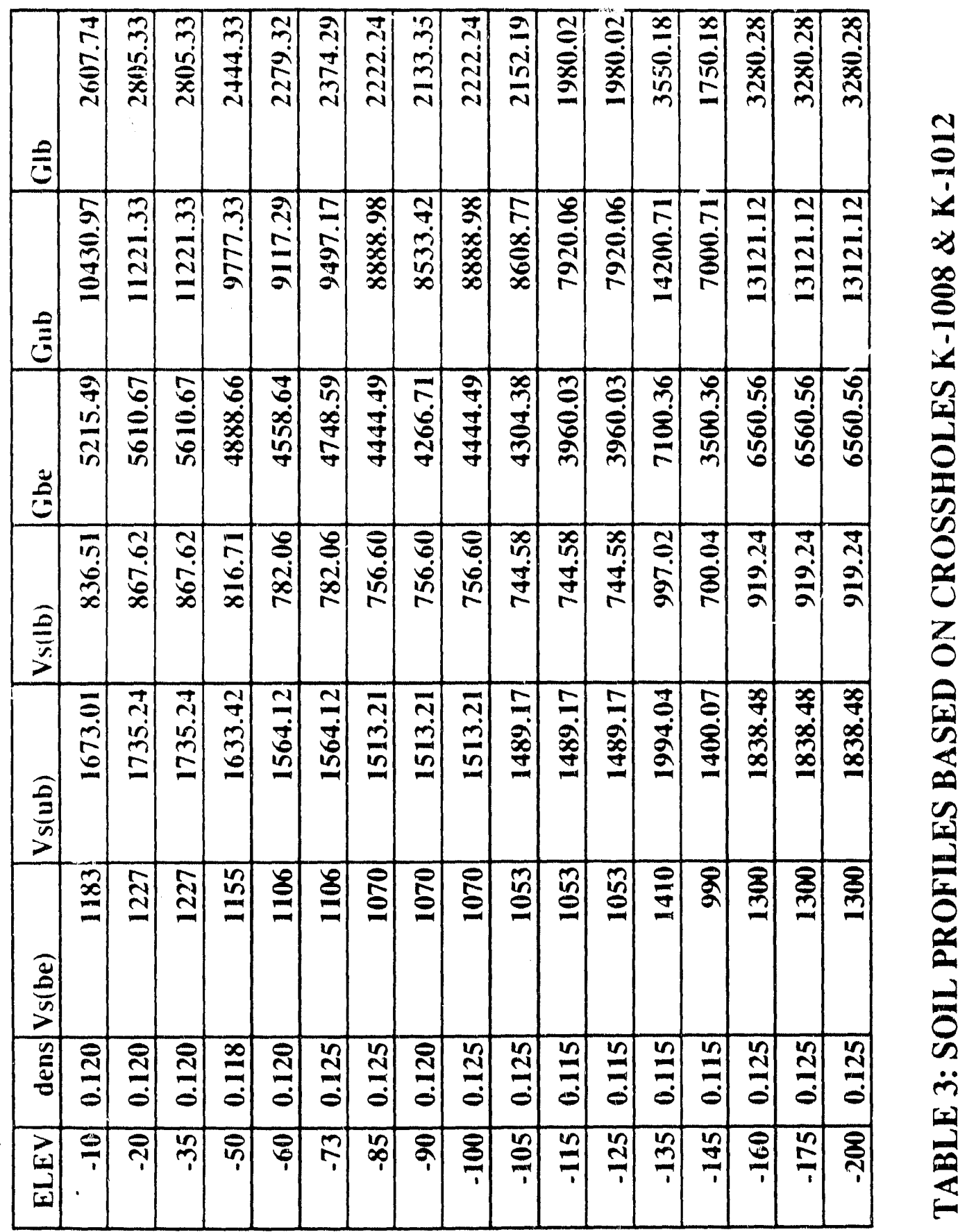




\begin{tabular}{|c|c|}
\hline WESTINGHOUSE SAVANNAH RITER COMPANY & WS RC- TR-91-+73 \\
\hline E\&PD SYSTEMS ENGINELKLAG & REVISION O \\
\hline SEISMIC STRUCTURAL ENGINEERING & AUGUST, 1991 \\
\hline K-REACTOR SOIL PROFILE STLDY & $\mathrm{PACE}$ Tt OF Tt \\
\hline
\end{tabular}

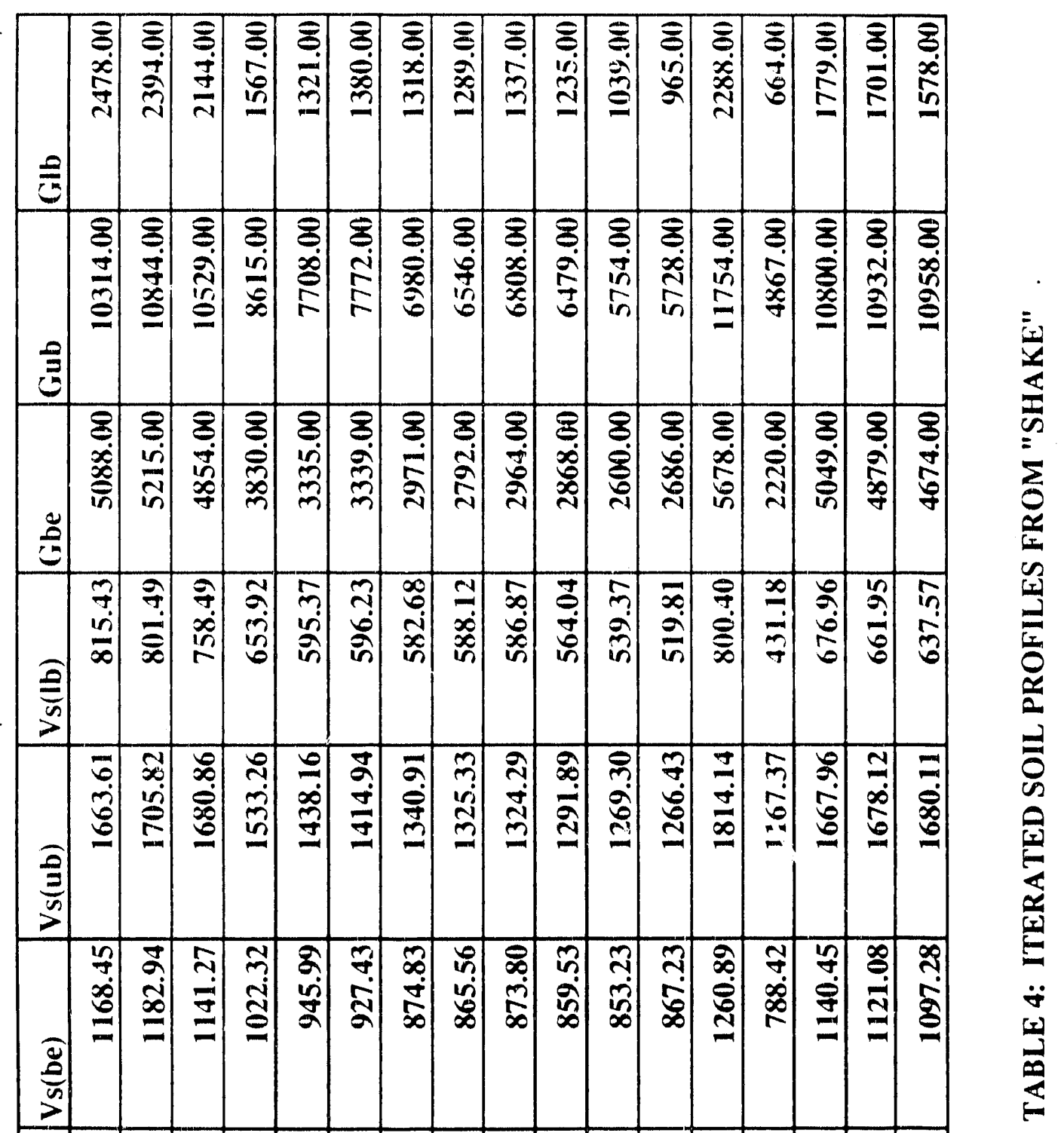


WESTINGHOLSE SAVANTIH RISK COMPANY

E\&PD SYSTEMS ENGINEERIN(;

SEISMIC STRUCTURAL ENGINFFRING

K-REACTOR SOLL PROFILE SILUY
WSRC-TR-91+473

REVISION 0

AUGUST, 1991

\section{FIGURES}




\begin{tabular}{|c|c|}
\hline SAVANNAII RIVER & IVSRC-TR. 91.473 \\
\hline EQPD SYSTEMS FNGINEFRING; & REVISION 0 \\
\hline SEISMIC STRLCTURAL ENGINEERING; & AUGUST, 1991 \\
\hline K-REACTOR SOIL PROFILE STLOY & PAGE F1 OF F31 \\
\hline
\end{tabular}

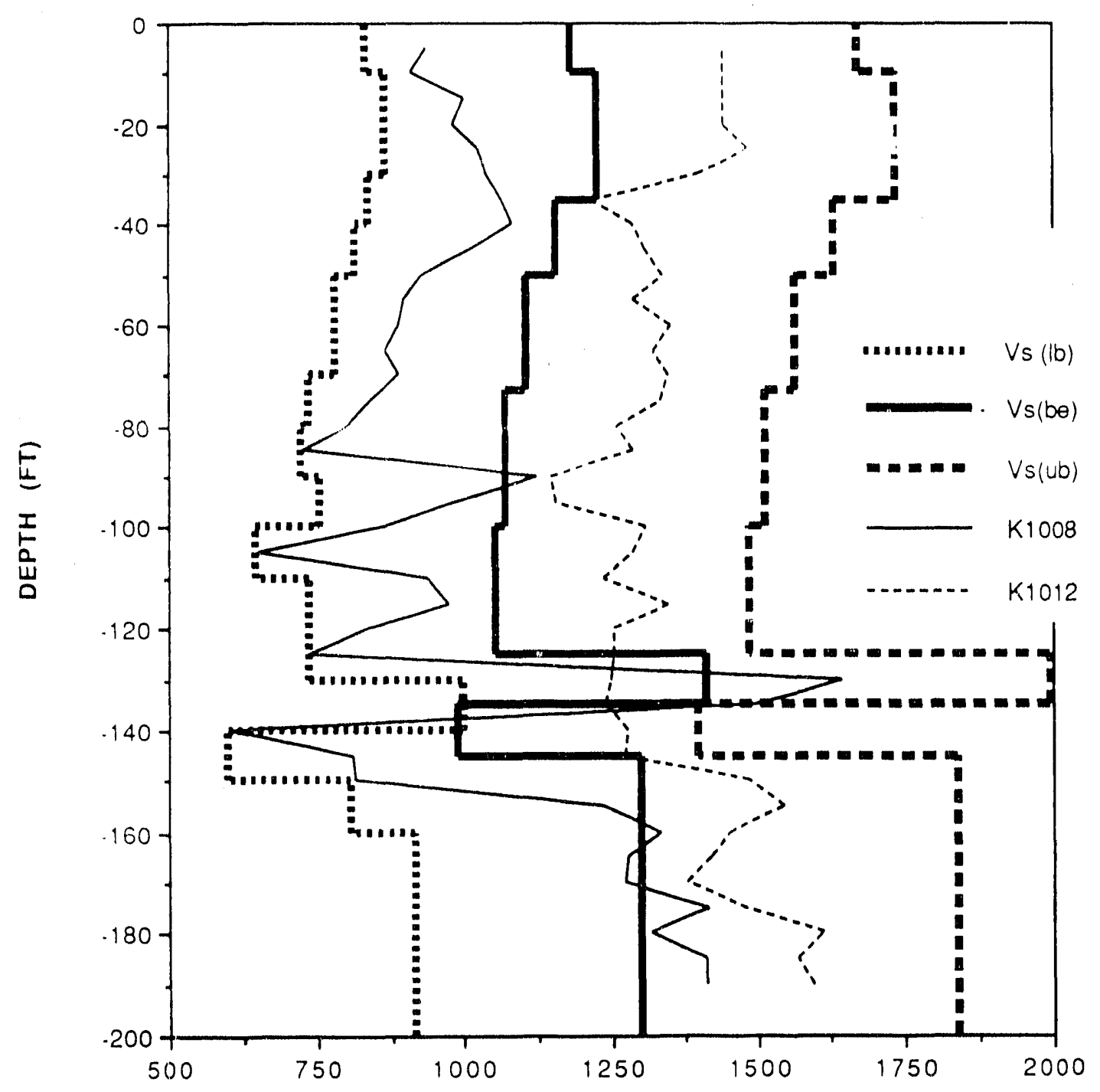

SHEAR WAVE VELOCITY

FIGURE 1: CROSSHOLES K1008 \& K1012 AND ANALYTICAL SOIL PROFILES 


\begin{tabular}{|c|c|}
\hline 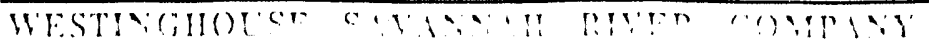 & $-T R-91+7.3$ \\
\hline RAL sYSLE:. & REVISHON () \\
\hline SEISMIC STRUCTURAL ENGINEERING; & AUGUST, \\
\hline K-REACTOR SOIL PROEILE SIILY & $P A(j E) F 2$ \\
\hline
\end{tabular}

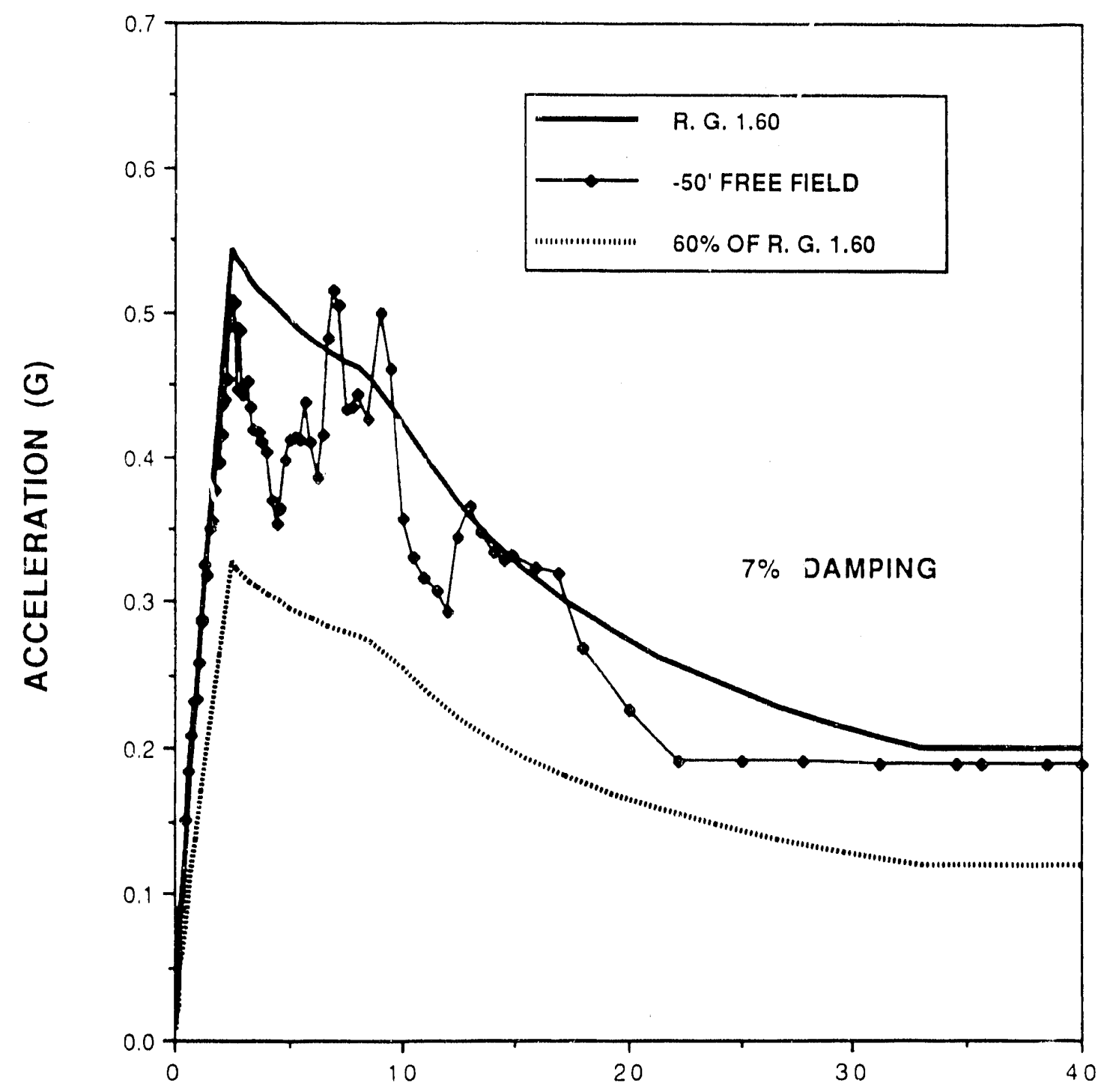

FREQUENCY $(\mathrm{HZ})$

FIGURE 2: ENVELOPED -50' FREE FIELD RESPONSE COMPARED TO REG. GUIDE 1.60 SPECTRA 


\begin{tabular}{|c|c|}
\hline WESTINGHOUSE SAVANNAH RIVER & WS R C.T R $-91 \cdot 473$ \\
\hline EADD SYSTEMS & REVISION 0 \\
\hline SEISMIC STRUCTURAL ENGINEERING & AUGUST, \\
\hline K.REACTOR SOIL PROFILF STLDY & PAGE F3 \\
\hline
\end{tabular}

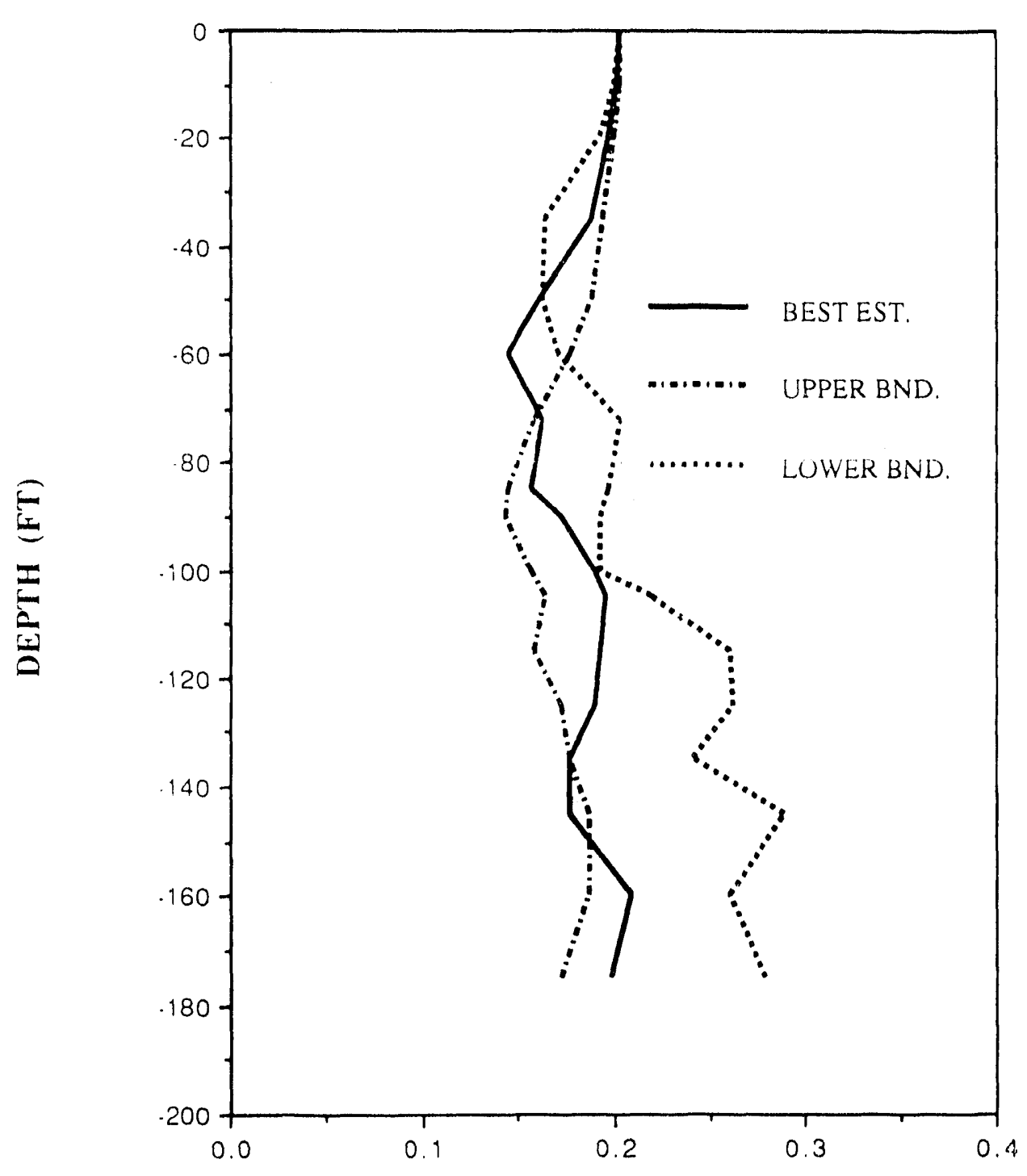

ACCELERATION (G)

FIGURE-3 VARIATION OF MAX. ACCELERATION WITH DEPTH FOR FREE FIELD ANALYSIS 


\begin{tabular}{|c|c|}
\hline 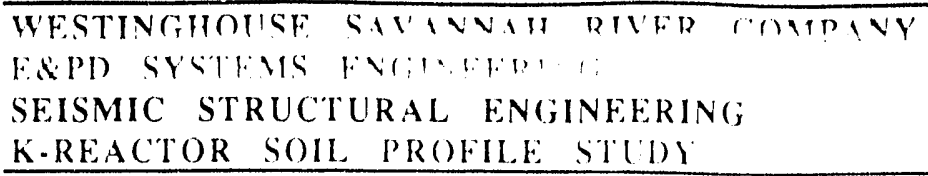 & $\begin{array}{l}\text { WSRC TR 91-17? } \\
\text { REYISIOY } 1 \\
\text { AUGUST, } 1991 \\
\text { PAGE FA OF F31 }\end{array}$ \\
\hline
\end{tabular}

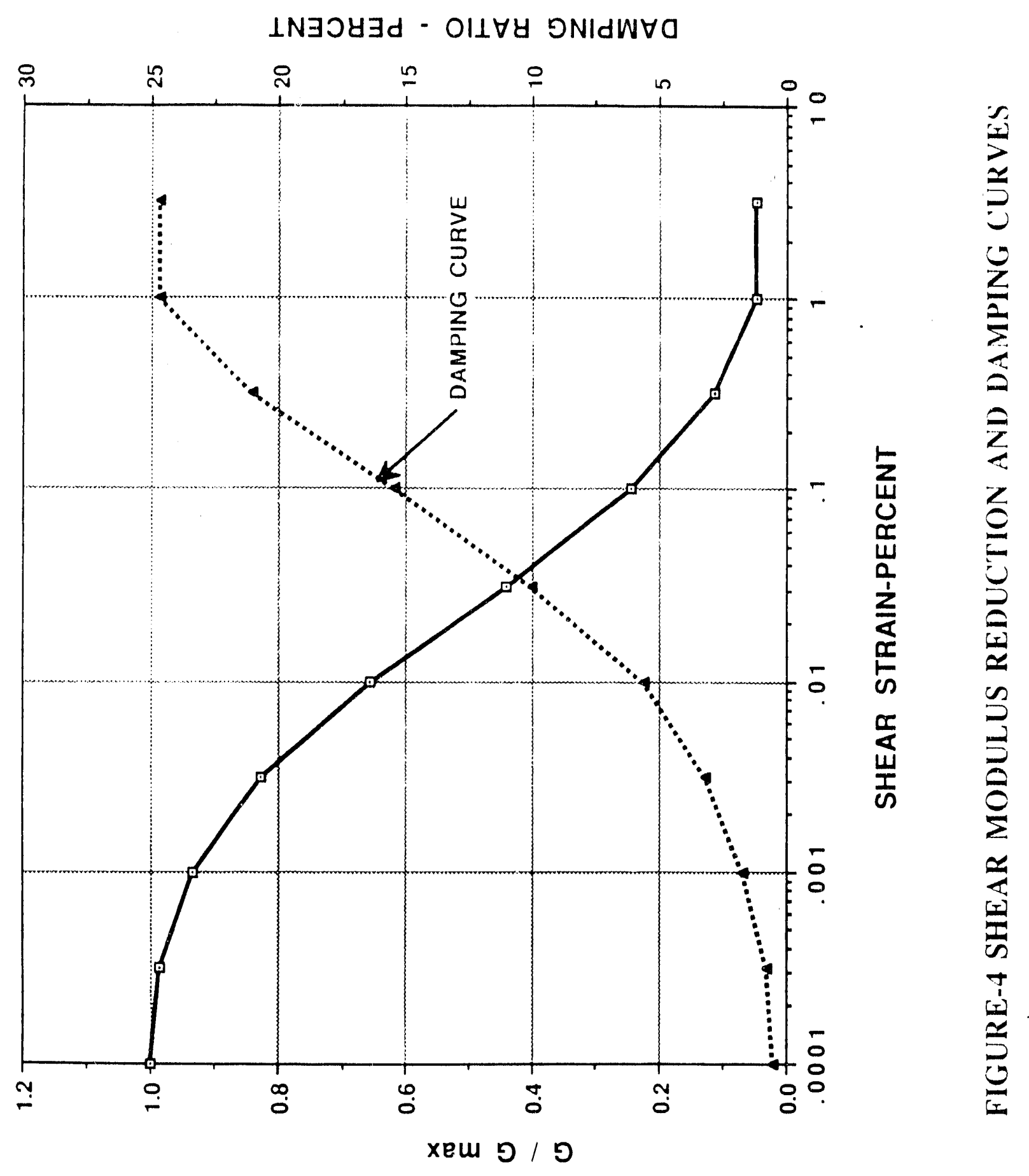


WESTINGHOUSE SAVANNAH RIVER COMPANY

F.RPD SYSTFMS FUGINPEDM"

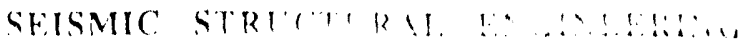

K-REACTOR SOIL PROFILE STUDY
WSR C-TR. $91 \cdot+73$

KiRISION ()

August, lyyl

PAGE F5 OF F31

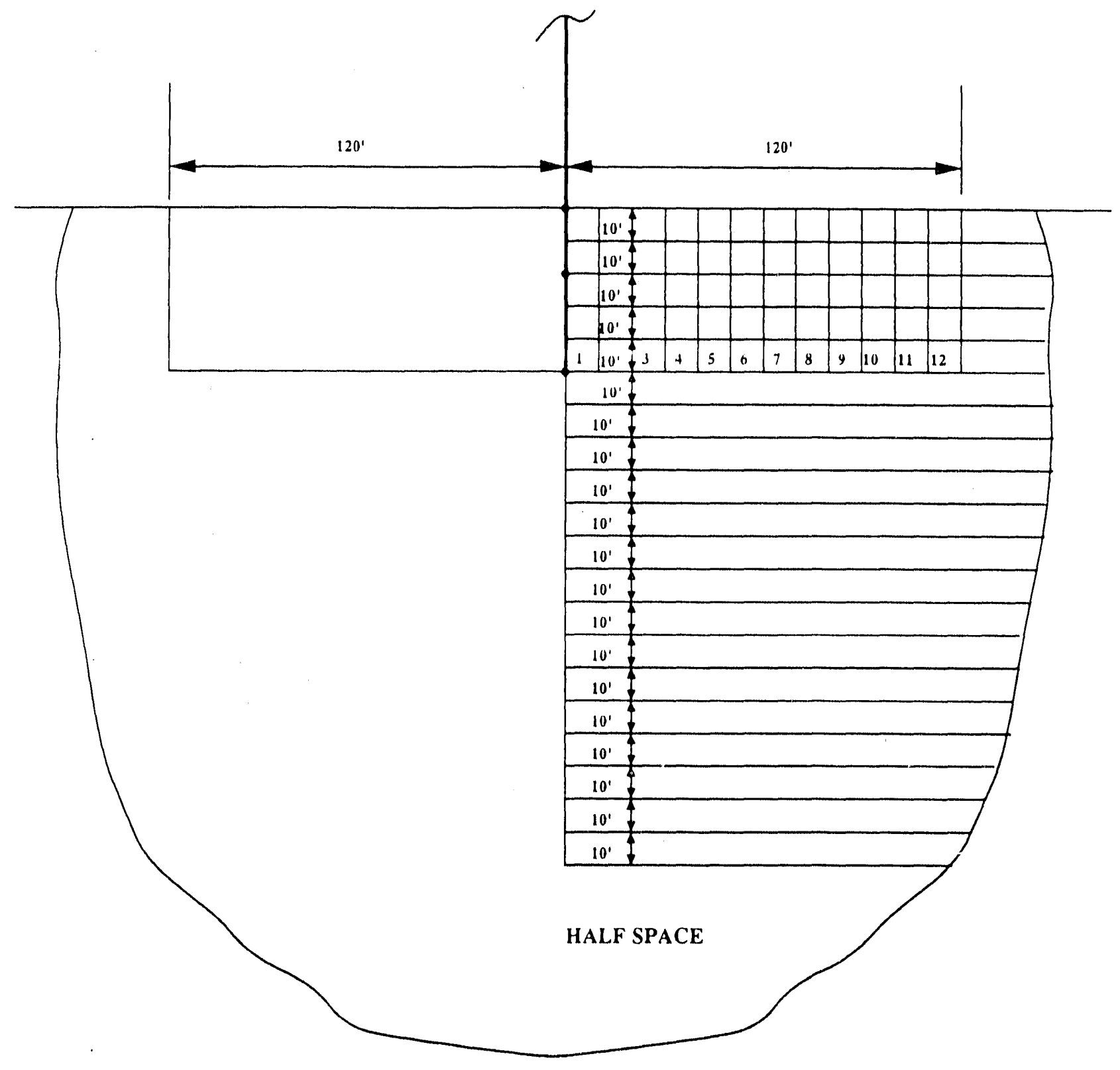

FIGURE 5: SOIL LAYERING FOR SASSI LOWER BOUND MODEL 
WESTINGHOUSF SAVANNAH RIVFR GOMPAVY

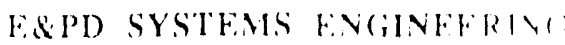

SEISMIC STRUCTURAL ENGINEERING;

K-REACTOR SOIL PROFIIE SILDY
WSRC.TR.91.t73

REVISION O

AUGUST, 1991

PACEE F6.1 OF F.1

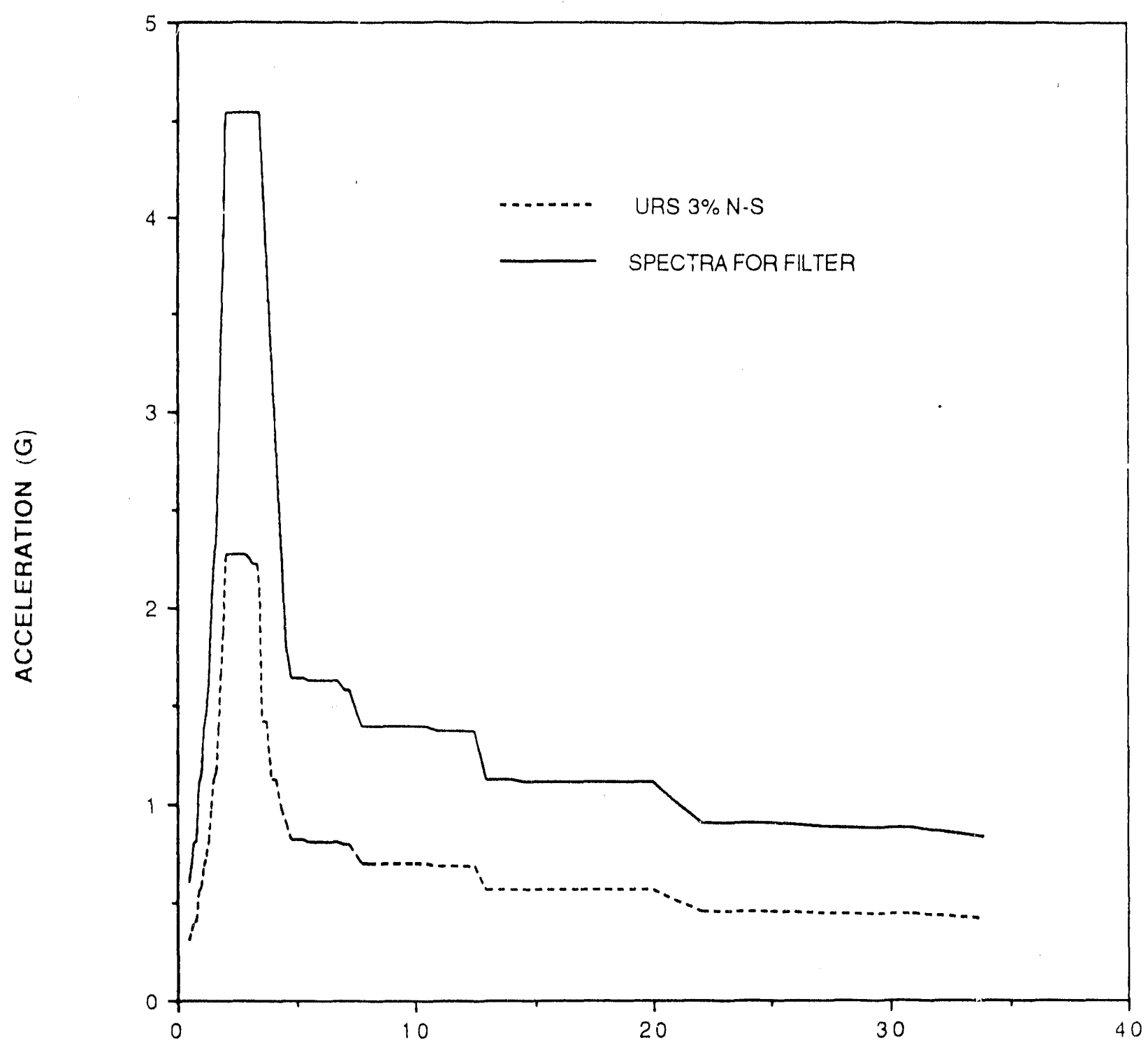

FREQUENCY (HZ)

FIGURE 6-1 105-K STACK BLDG ELEV. 55 FT N-S SMOOTHED FRS AND THE SPECTRUM FOR FILTER COMPARTMENT ANALYSIS 
WESTINGHOUSE SAVANNAH RIVER C'(DMLPANY E\&PD SYSTEMS ENGINEFRING

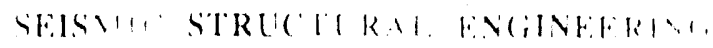

K-REACTOR SOIL PROFILE STUDY
WSR C - TR - 91 1 +73

RFVISION O

$11(: 1,1), 101) 1$

PACE F6.2 ()F F31

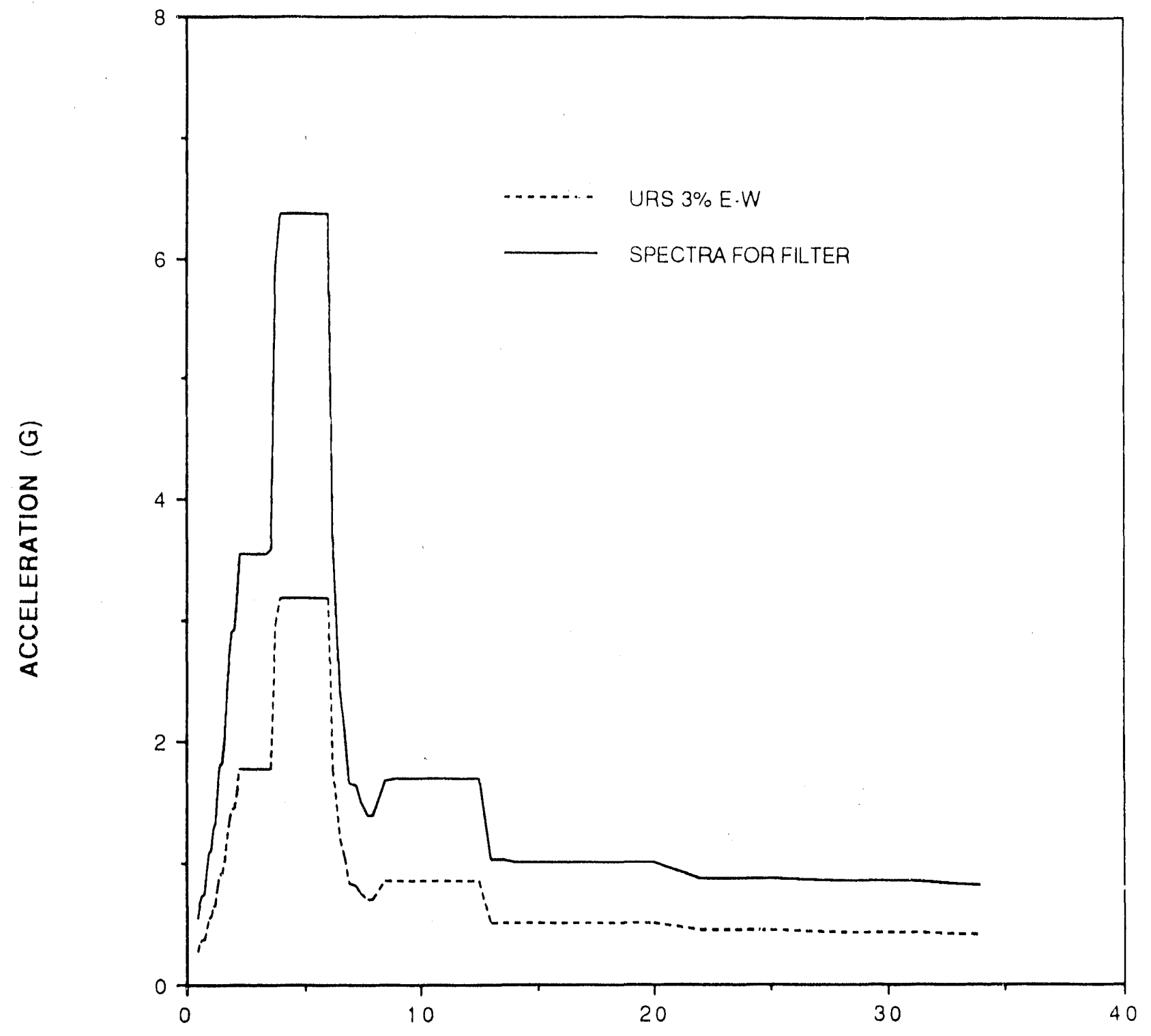

FREQUENCY $(\mathrm{HZ})$

FIGURE 6-2 105-K STACK BLDG ELEV. 55 FT E-W SMOOTHED FRS AND THE SPECTRUM FOR FILTER COMPARTMENT ANALYSIS 
WESTINGHOUSF SAVAVNAH RIIFR GOMPIVY

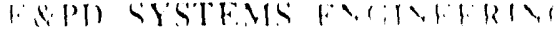

SEISMIC STRUCTURAL ENGINEERING

K-REACTOR SOIL PROFILE STIDY
IVSRC.TP.01.17?

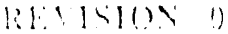

AUGUST, 1991

PA(SE: Fo. () () F F 31

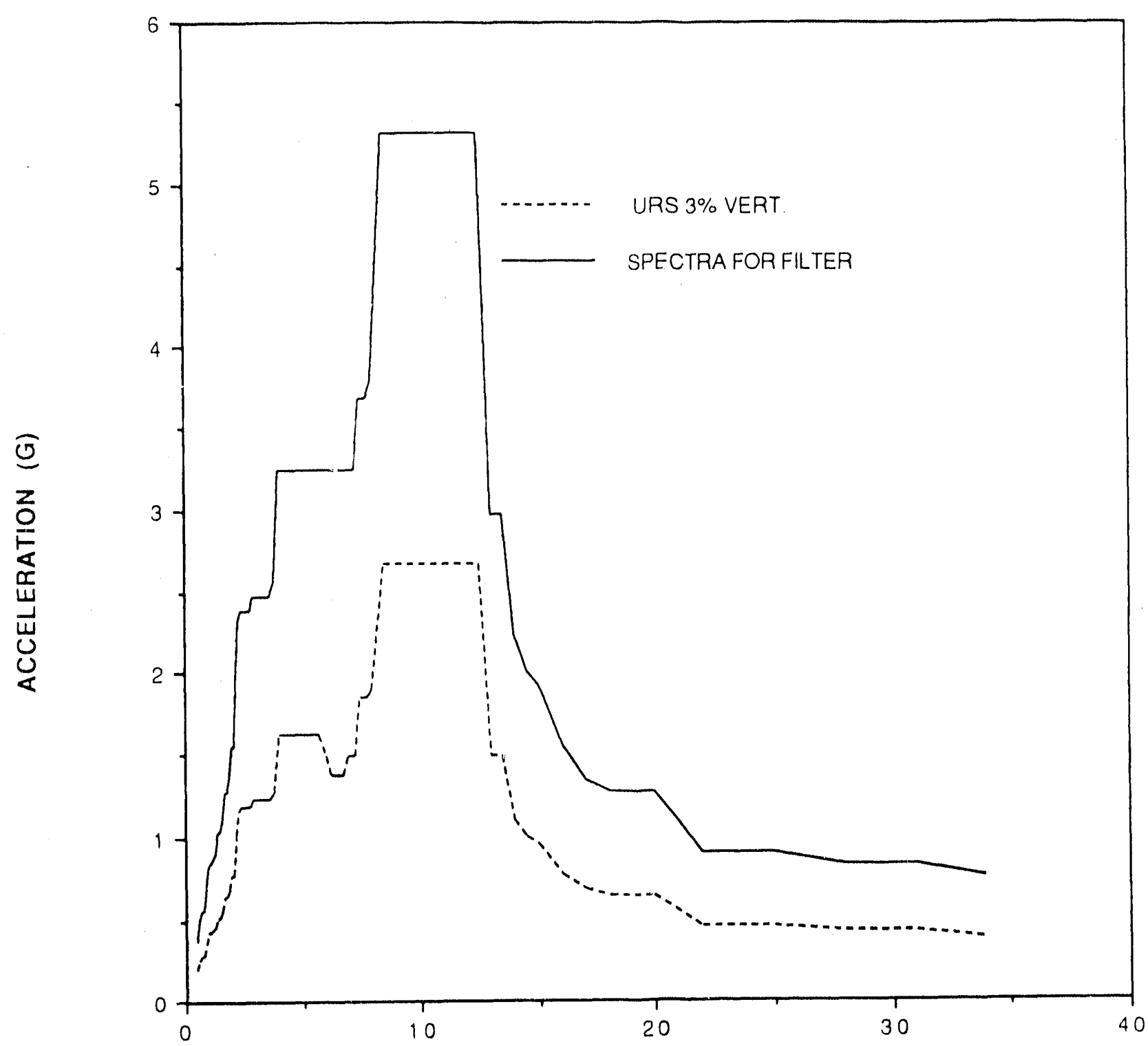

FREQUENCY $(\mathrm{HZ})$

FIGURE 6-3 105-K STACK BLDG ELEV. 55 FT VERTICAL SMOOTHED FRS AND THE SPECTRUM FOR FILTER COMPARTMENT ANALYSIS 
WESTINGHOUSE SAVANVAH RIVER COMPANY EAPD SYSTEMS ENGINEFRIVG;

SEISMIC STRUCTURAL ENGINEERING

K-REACTOR SOIL PROFILE STUDY
WSR ('-TR R $91-+73$

REVISION O

AUGUST, 1991

PACE F7 OF F31

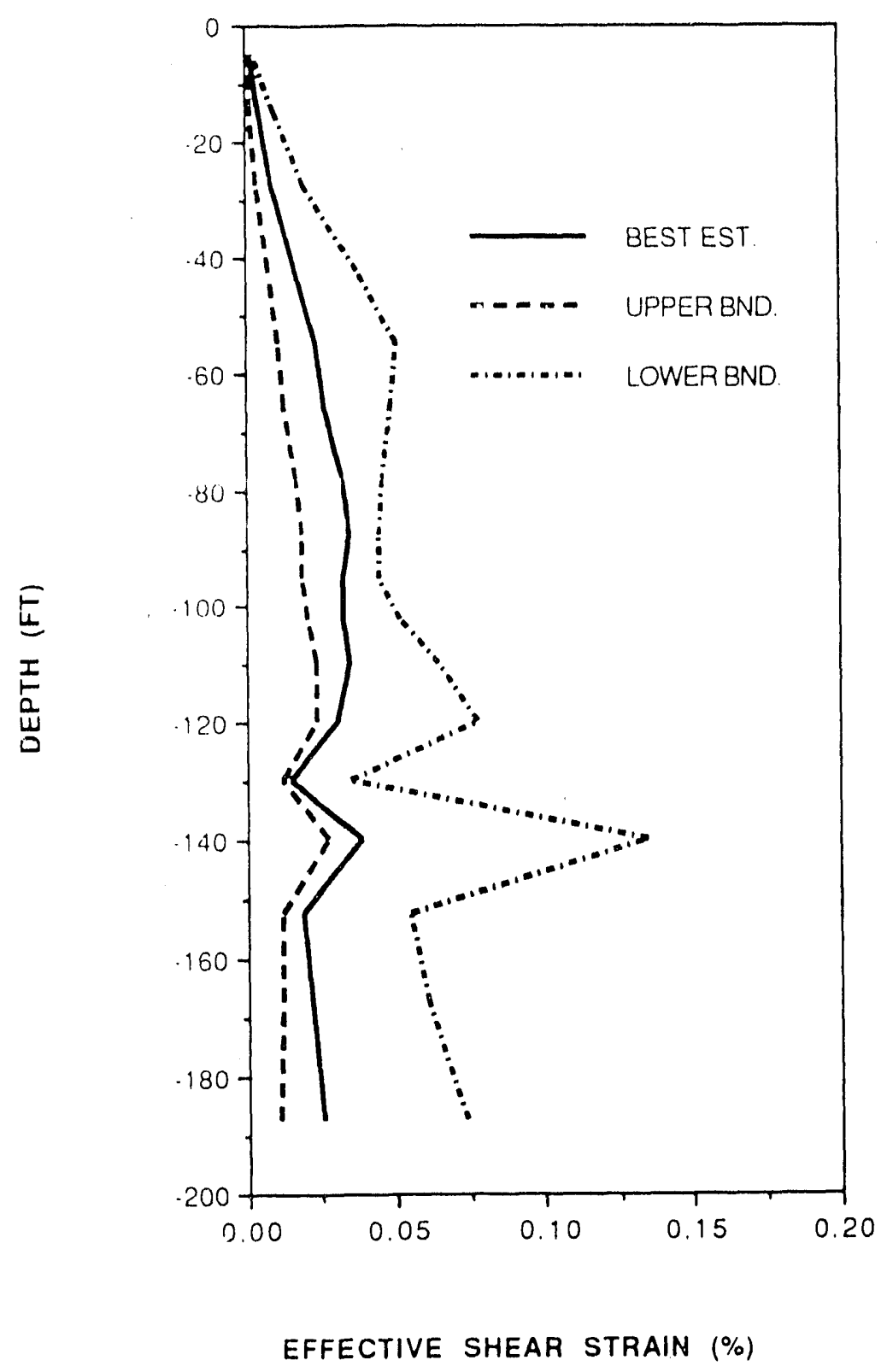

FIGURE 7 VARIATION OF EFFECTIVE STRAIN WITH DEPTHFOR FREE FIELD

FREE FIELD ANALYSIS 
WESTINGHOUSE SAVANVAH RIVFR COMPIVY

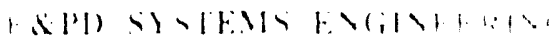

SEISMIC STRLC'TURAL FUIINEFRING

K-REACTOR SOHI. PROFIIE STIDY
WSRC.TR.41.473

I:P $\backslash 4 \| 11$

AUGUST, 1991

PA(jE F8 OF F31

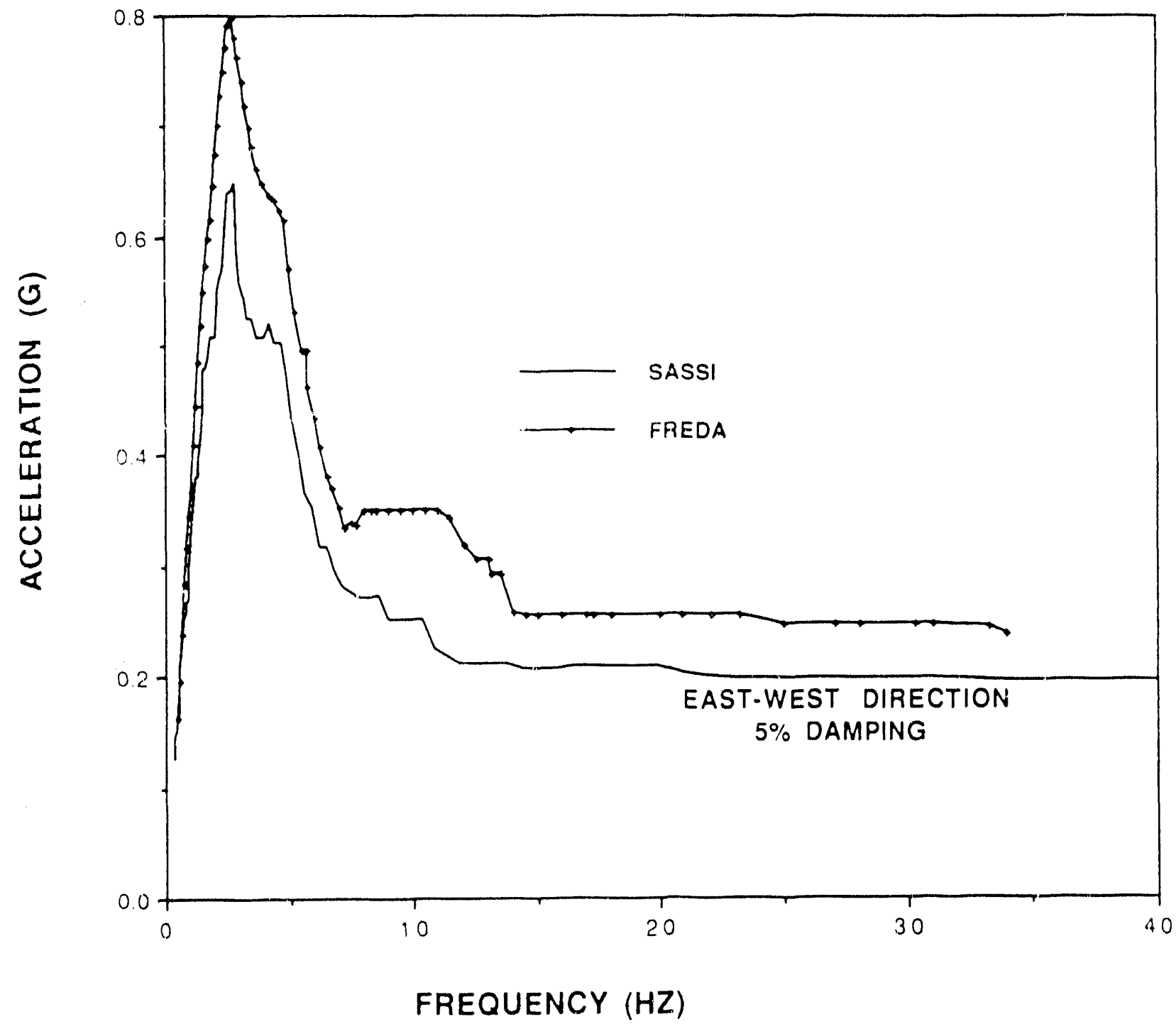

FIGURE 8: COMPARISON OF FREDA FRS, AND SASSI FRS WITH NEW SOIL PROPERTIES FOR THE K-REACTOR, ELEVATION - 20 FT. 
WESTINGHOISF SAVANVAH RISFD GOMPIN'

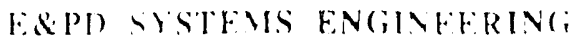

SEISMIC STRUCTURAL ENGINEERIN(;

K-REACTOR SOIL PROFILE TILDY
IVSRC.TR.91-473

REIISIOY 0

AUGUSl, 1991

PA(FE F9 OF F31

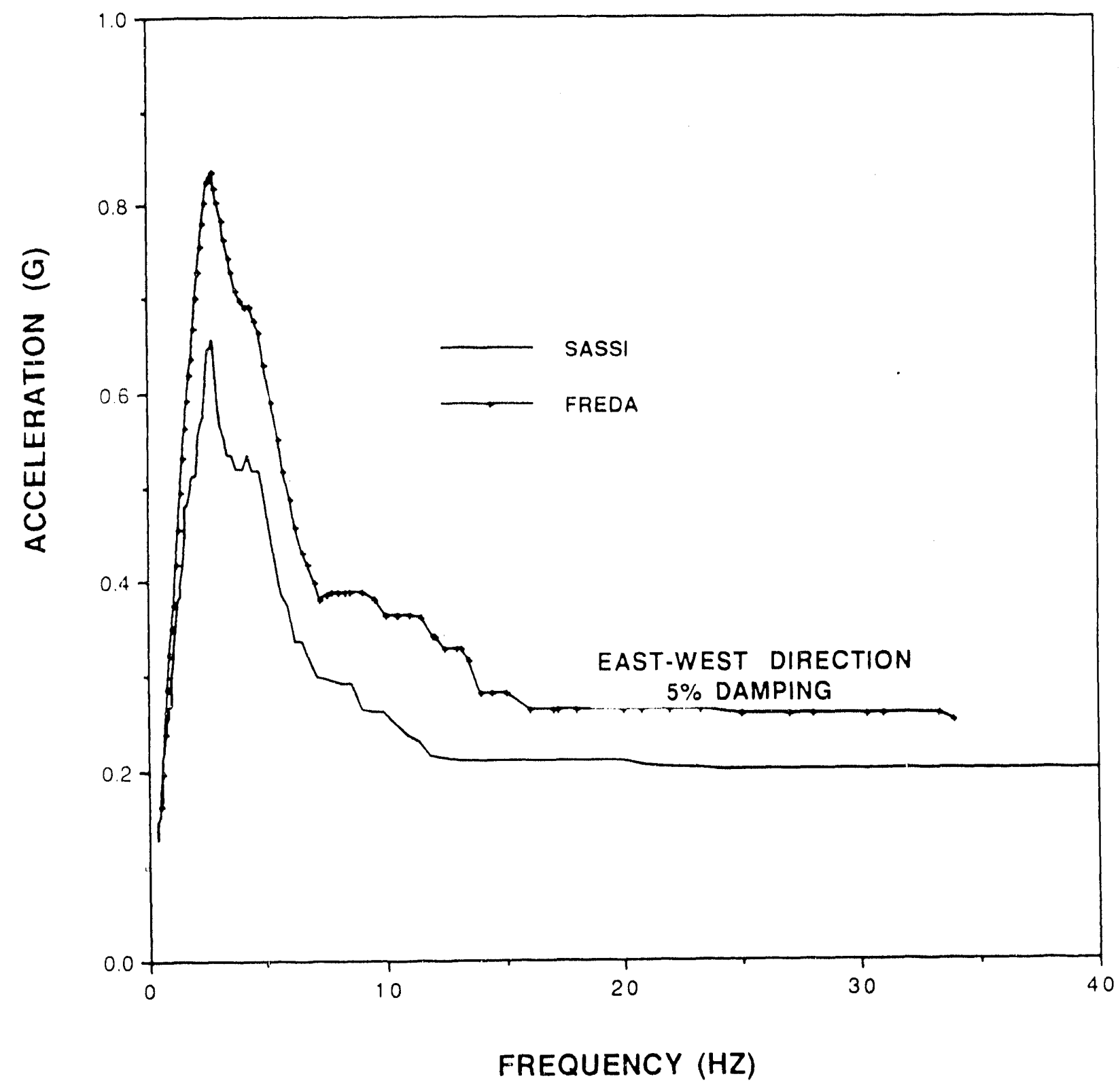

FIGURE 9: COMPARISON OF FREDA FRS, AND SASSI FRS WITH NEW SOIL PROPERTIES FOR THE K-REACTOR, ELEVATION 0 FT. 
WESTINGHOUSF SAVANNAH RIVER COMPAVY

ESPD SYSTEMS FNGINEFRING;

SEISMIC STRUCTURAL ENGINEERINC;

K-REACTOR SOIL PROFILE STUDY
II SR ( - TR -9$) 1 \cdot+7.3$

REVISION ()

A LiGUST, 1991

PA(iF F10 ()F F 31

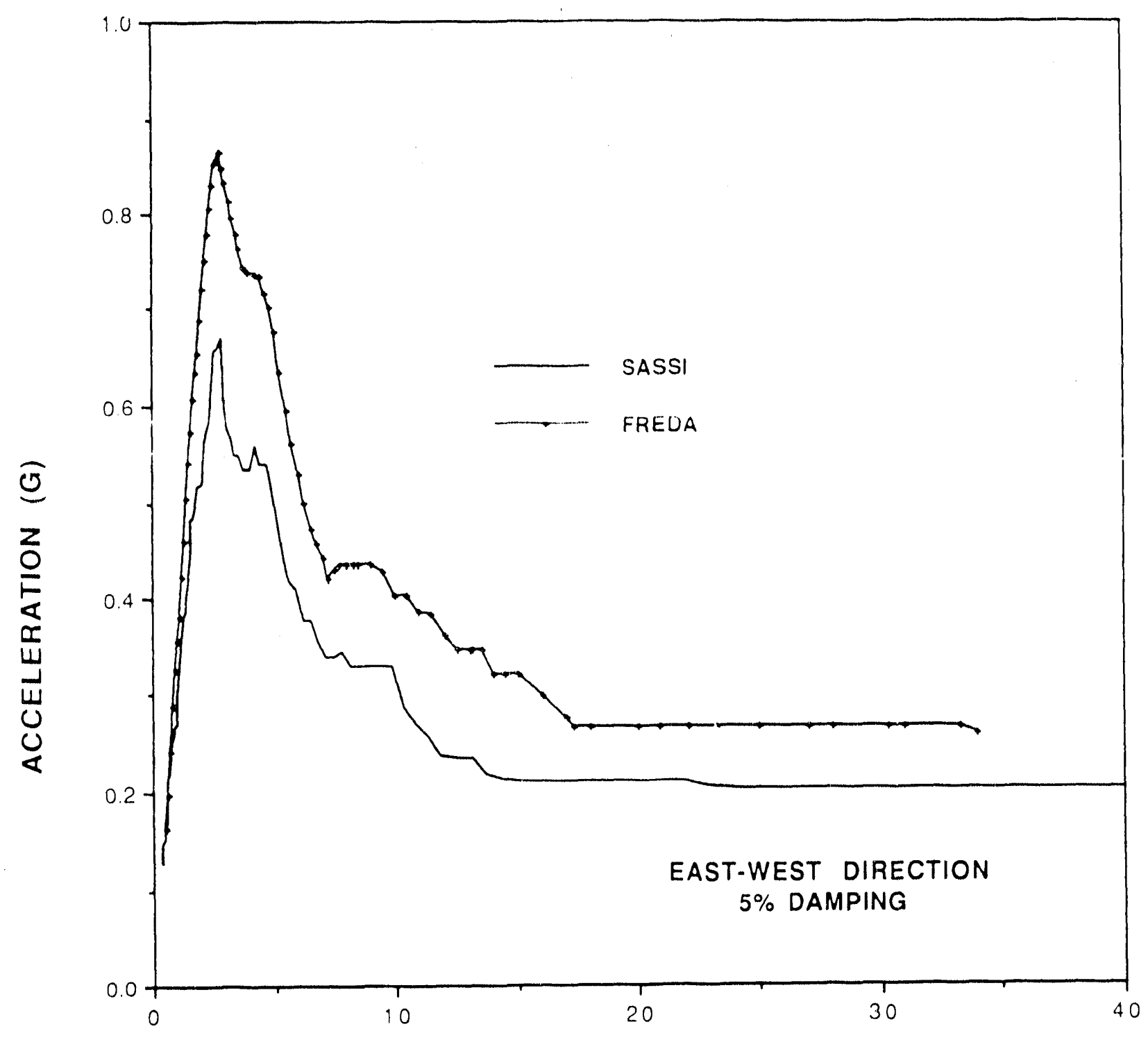

FREQUENCY (HZ)

FIGURE 10: COMPARISON OF FREDA FRS, AND SASSI FRS WITH NEW SOIL PROPERTIES FOR THE K-REACTOR, ELEVATION + 15 FT. 


\begin{tabular}{|c|c|}
\hline WESTINGHOUSE SAVANNAH RIVFR COMPANY & WSRC.TR.01.473 \\
\hline KEPD SYS IN ENGINEFKING & REVISION 0 \\
\hline SEISMIC STRUCTURAL ENGINEERING & AUGUST, 1991 \\
\hline K-REACTOR SOIL PROFILE STUDY & PACBE F11 OF F 31 \\
\hline
\end{tabular}

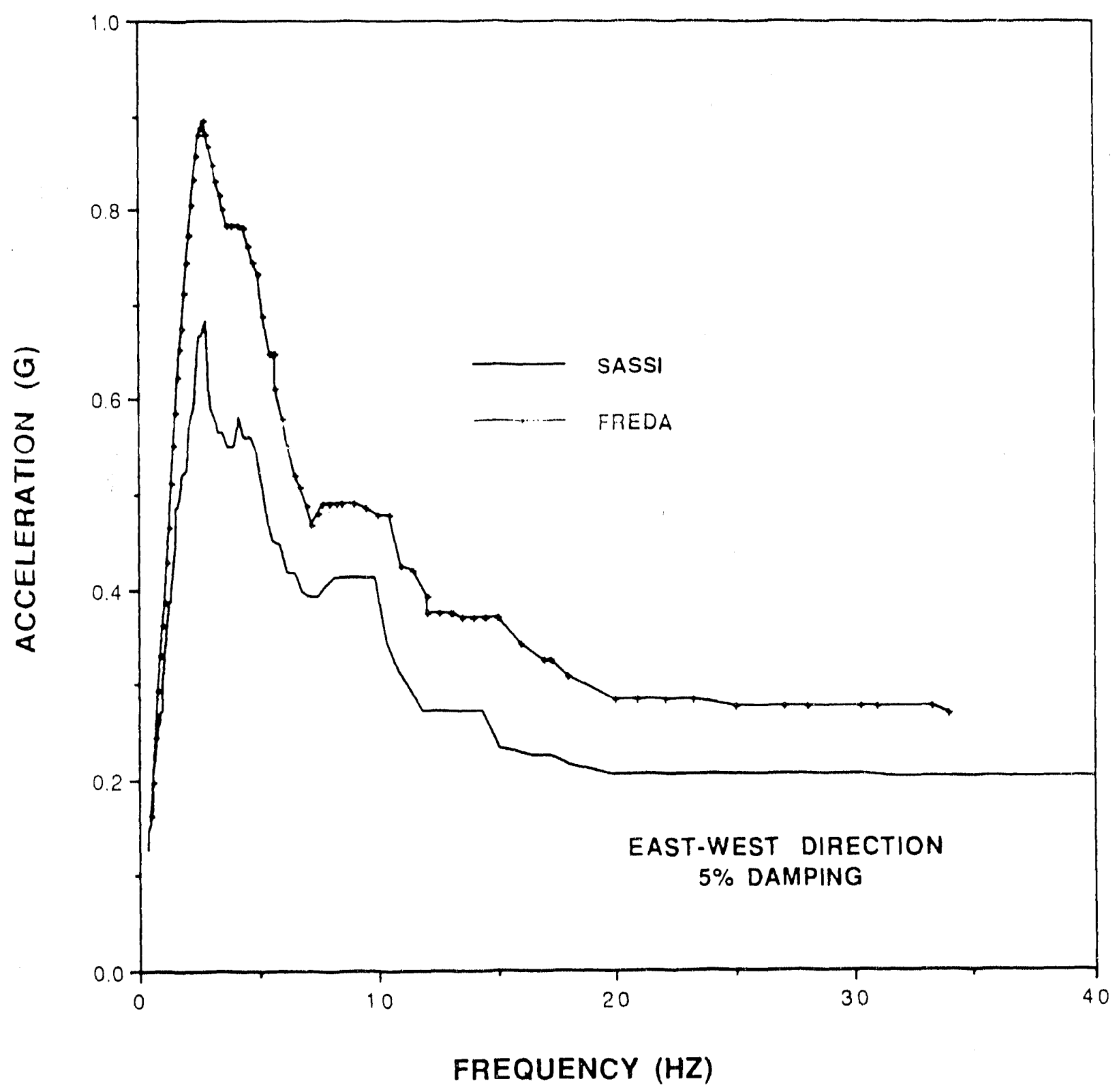

FIGURE 11: COMPARISON OF FREDA FRS, AND SASSI FRS WITH NEW SOIL PROPERTIES FOR THE K-REACTOR, ELEVATION + 34 FT. 


\begin{tabular}{|c|c|}
\hline WESTINGHOESE SAVANNAH RIVFR COMPAVY & WSR('.TR.9)1.+73 \\
\hline E\&PD SYSTEMS ENGINEERIYG; & REVISION \\
\hline SEISMIC STRUCTURAL ENGINEERING; & AUGUST, 1991 \\
\hline K-REACTOR SOIL PROFIIE STIDY & PACE F12 OF F31 \\
\hline
\end{tabular}

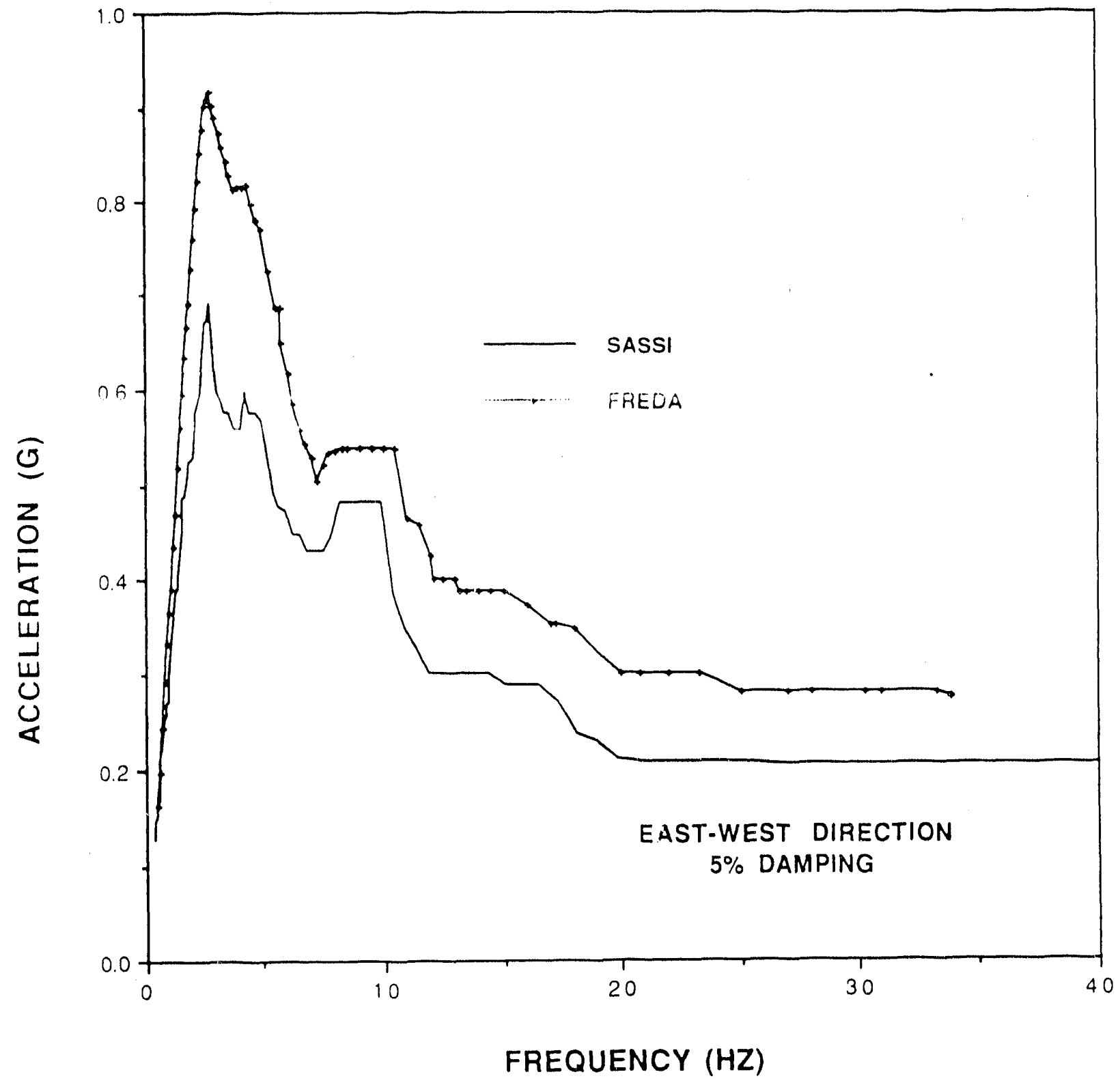

FIGURE 12: COMPARISON OF FREDA FRS, AND SASSI FRS WITH NEW SOIL PROPERTIES FOR THE K.REACTOR, ELEVATION + 48 FT. 
IVESTINGHOUSE SAVANNAH RIVFR (OMPANY F.PPD SYSTEMS, , HERINC;

SEISMIC STRUC'TURAL ENGINEERING;

K-REACTOR SOIL PROFIIE STIDY'
WSR ( . TR R 9 1- +73

Ki. :ISII) N 0

AUGUST, 1991

P.AGF F13 OF F31

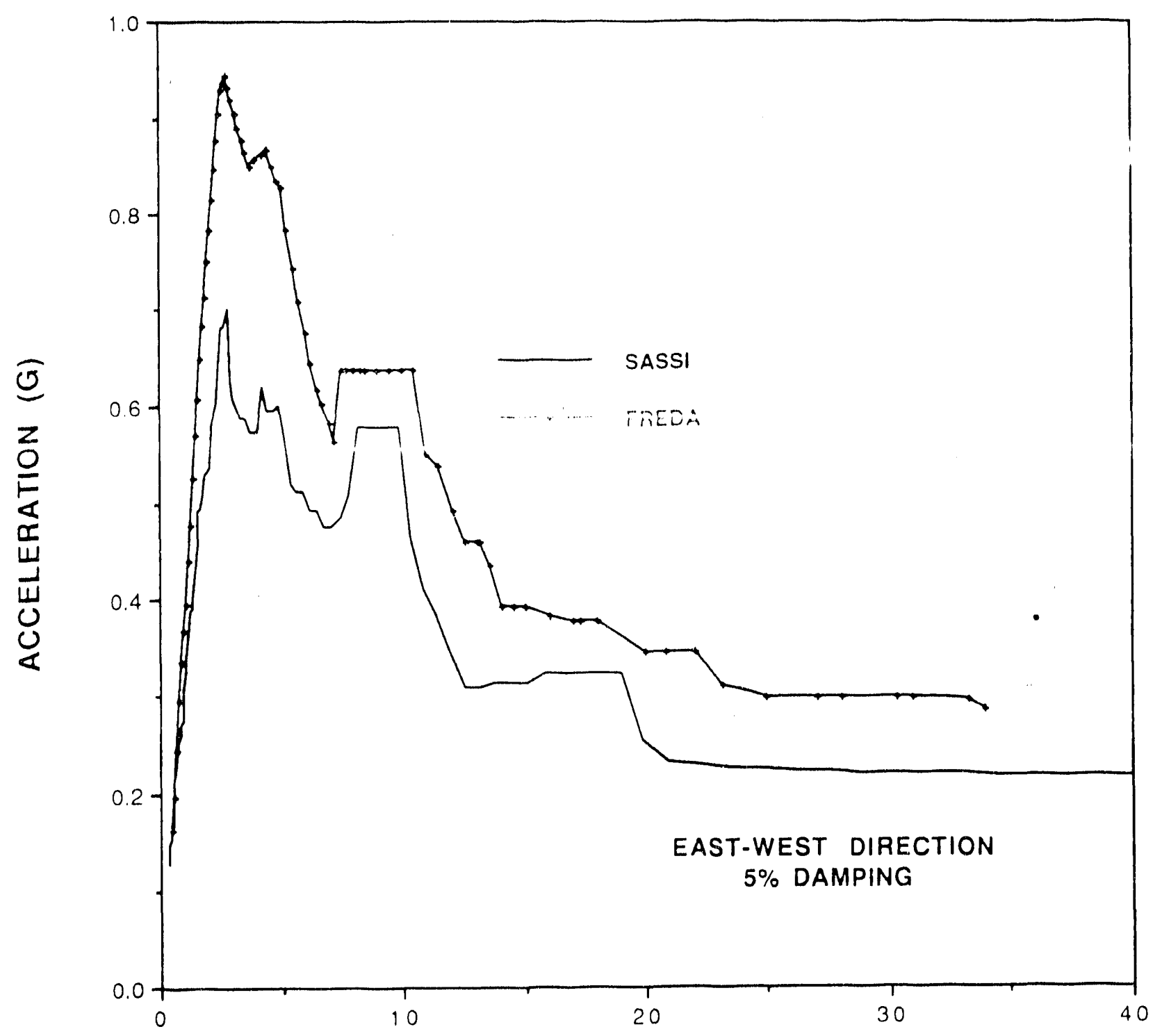

FREQUENCY (HZ)

FIGURE 13: COMPARISON OF FREDA FRS, AND SASSI FRS WITH NEW SOIL PROPERTIES FOR THE K-REACTOR, ELEVATION +66 FT. 
WESTINGHOUSE SAVANNAH RIVER COMPANY

FEPD SYSTEMS ENGINEFRING

SEISMIC STRUCTURAL ENGINEERING

K-REACTOR SOIL PROFILE STUDY
IVSRC.TR-91+473

RFVISION 0

AUGUSl, 1991

PACF F1+ OF F31

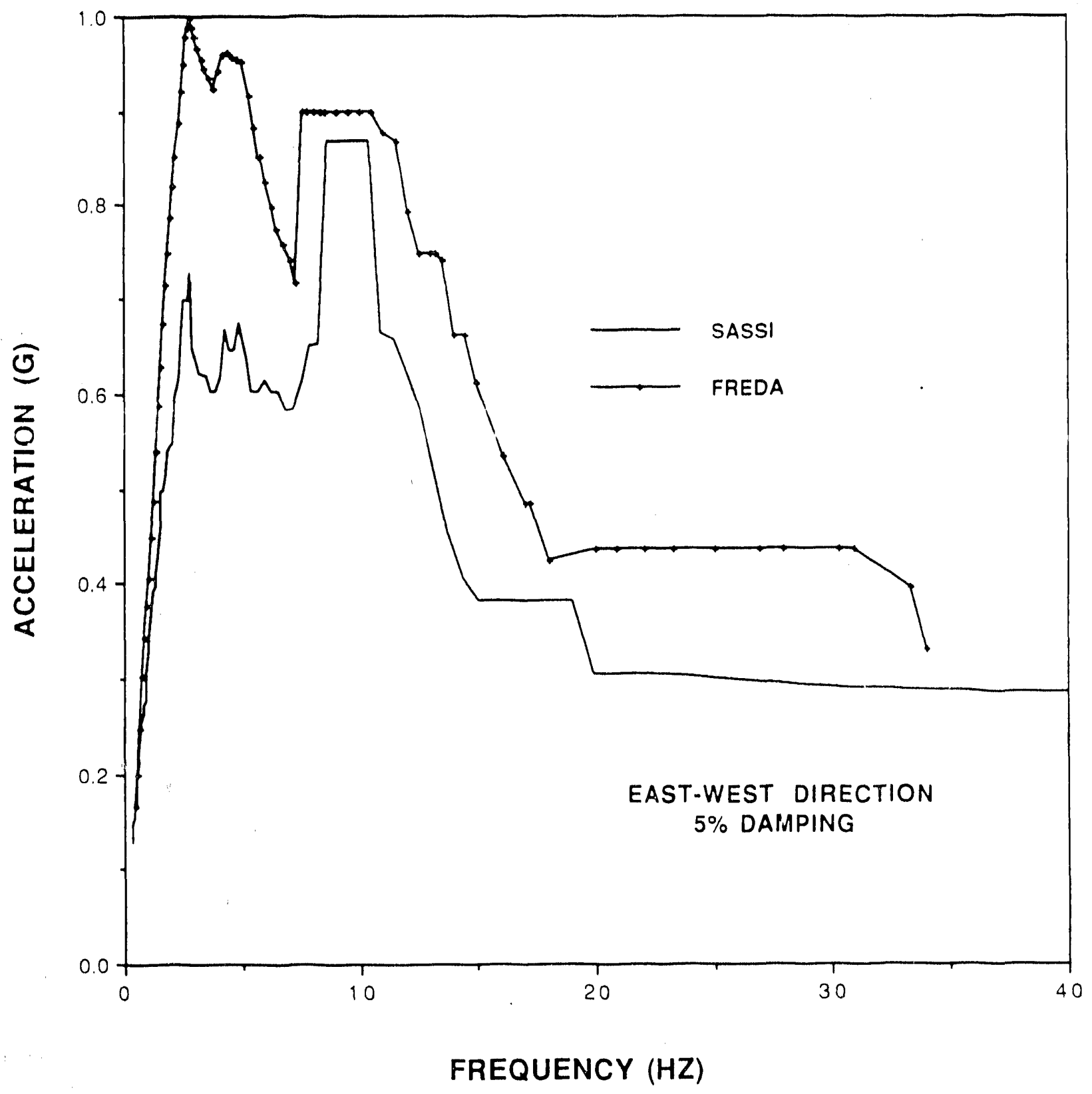

FIGURE 14: COMPARISON OF FREDA FRS, AND SASSI FRS WITH NEW SOIL PROPERTIES FOR THE K-REACTOR, ELEVATION +91.25 FT. 


\begin{tabular}{|c|c|}
\hline WESTINGHOESE SAVAY AII RISER (O)MPAYI & HSR $(\cdot 1 R-9) 1 \cdot+7.3$ \\
\hline LNPD SYSTEMS ENGINETRING & KEVISION O \\
\hline SEISMIC STRUCTURAL ENGINEERING; & AUGuST, \\
\hline K.REACTOR SOIL PROFHE STUDY & PACBE FIS OF F.31 \\
\hline
\end{tabular}

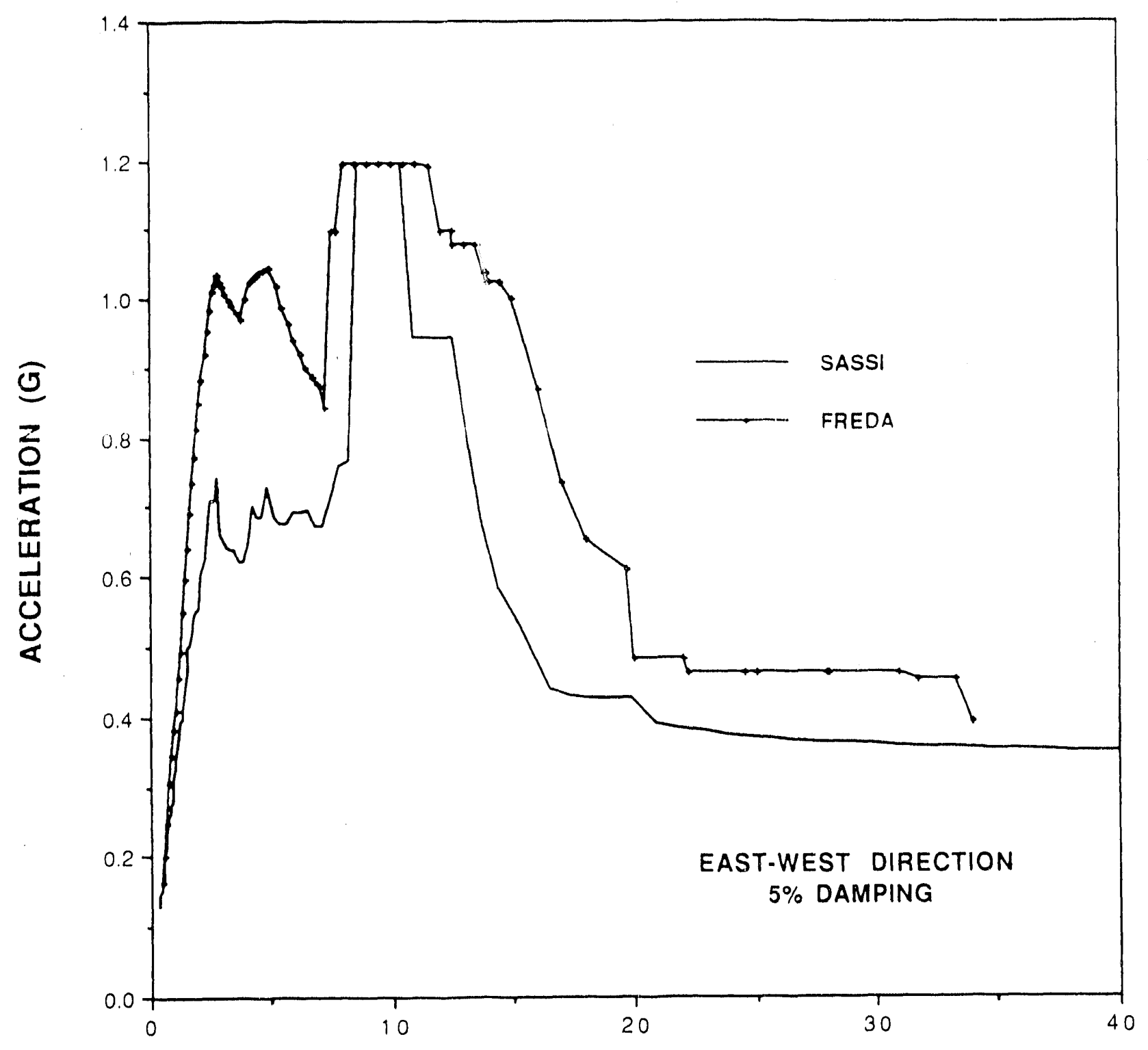

FREQUENCY (HZ) 
WESTINGHOESF SAVANYIII RIVER IOMTIY

LAPD SYSTFMIS ENGINEERIMI;

SEISMIC STRUCTURAL ENGINEFRING;

K-REACTOR SOLL PROFILE STUIIY
WSR $\left(\cdot T R \cdot 91+t^{-3}\right.$

REVISIOS I"

AUGUST, 1991

PAliE F16 OF H31

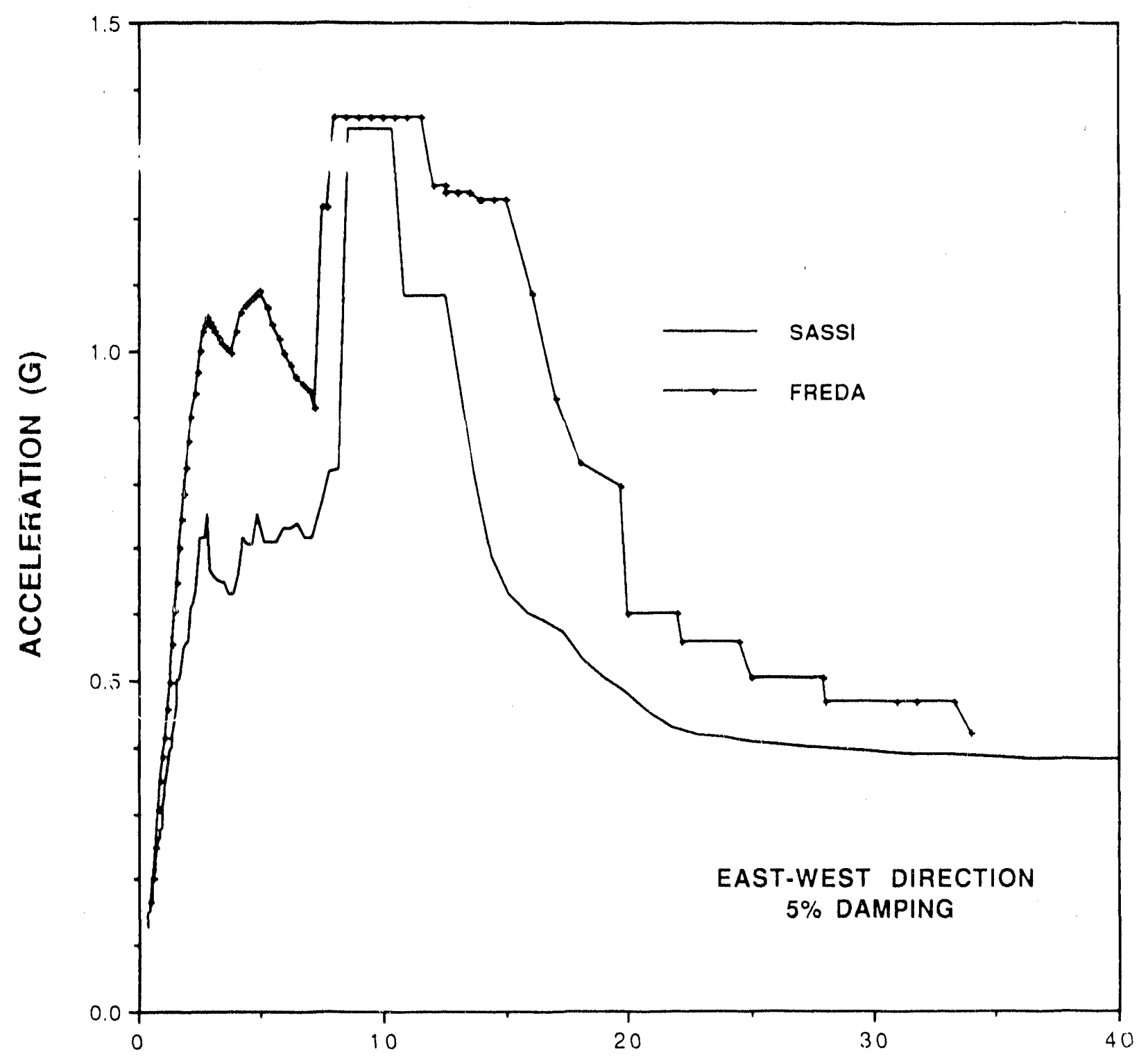

FREQUENCY (HZ)

FIGURE 16: COMPARISON OF FREDA FRS, AND SASSI FRS WITH NEW SOIL PROPERTIES FOR THE K-REACTOR, ELEVATION + 120 FT. 


\begin{tabular}{|c|c|}
\hline WESTINGHOLSE SAVANVAH RIVFR CONPIVY & WSP(C.TR.9) $1 \cdot t^{-1} 3$ \\
\hline FEPD SYSTEMS ENGINGFRI & REVISION O \\
\hline SEISMIC STRUCTURAL ENGINEERING; & AUGUST, 1991 \\
\hline K-REACTOR SOIL PROFILE SILDY & PACE $\mathrm{F} 17$ OF F31 \\
\hline
\end{tabular}

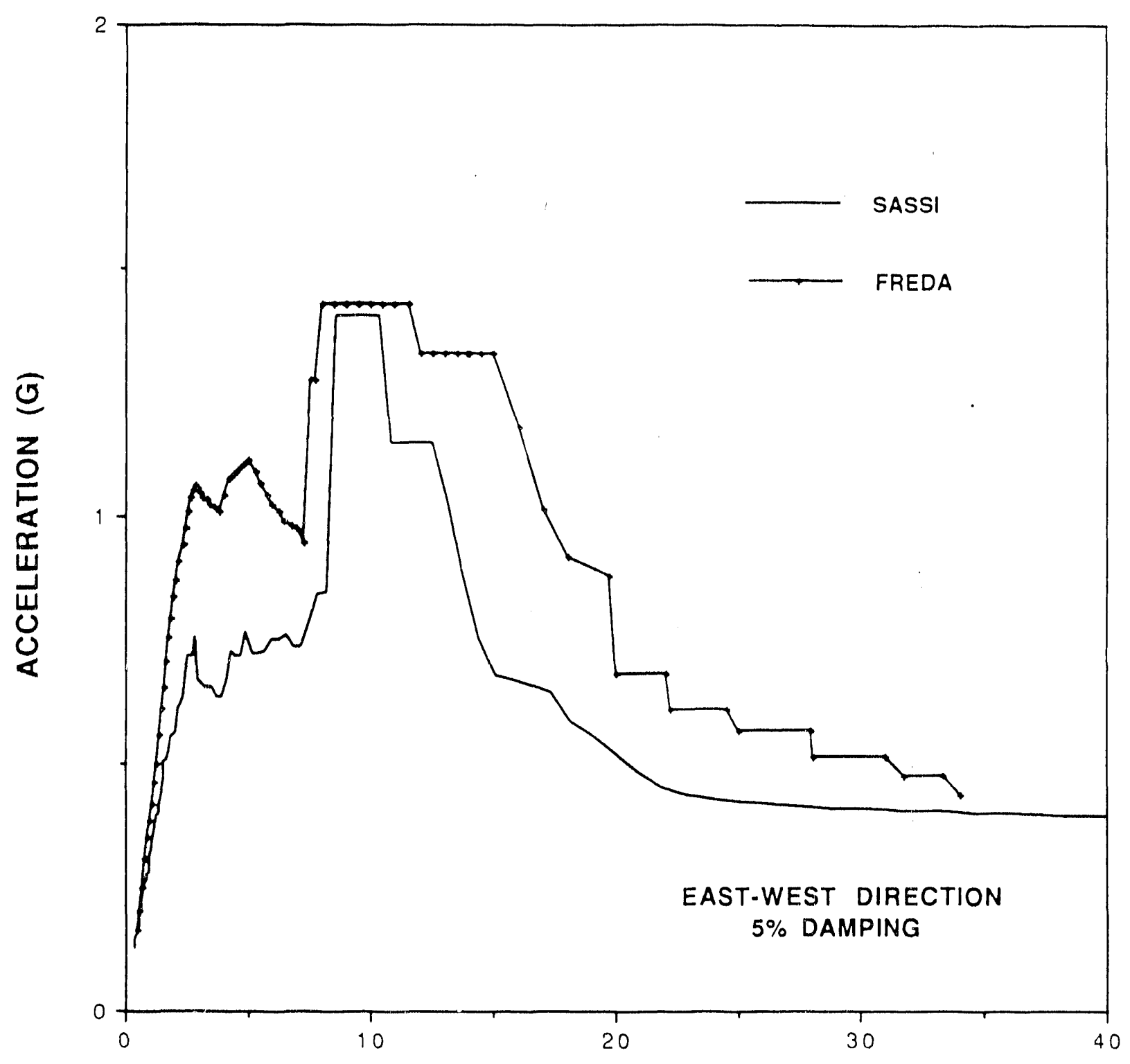

FREQUENCY (HZ) 


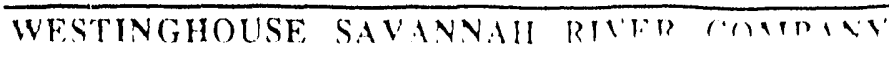
FEPD SYSTEMS ENCIVEFRING;

SEISMIC STRUCTURAL EN(INEFRIN(;

K-REACTOR SOIL PROFILE STLUY

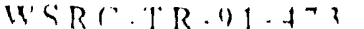

PFVISIOY

AUGUST, 1991

PAC FE F18 ()F F31

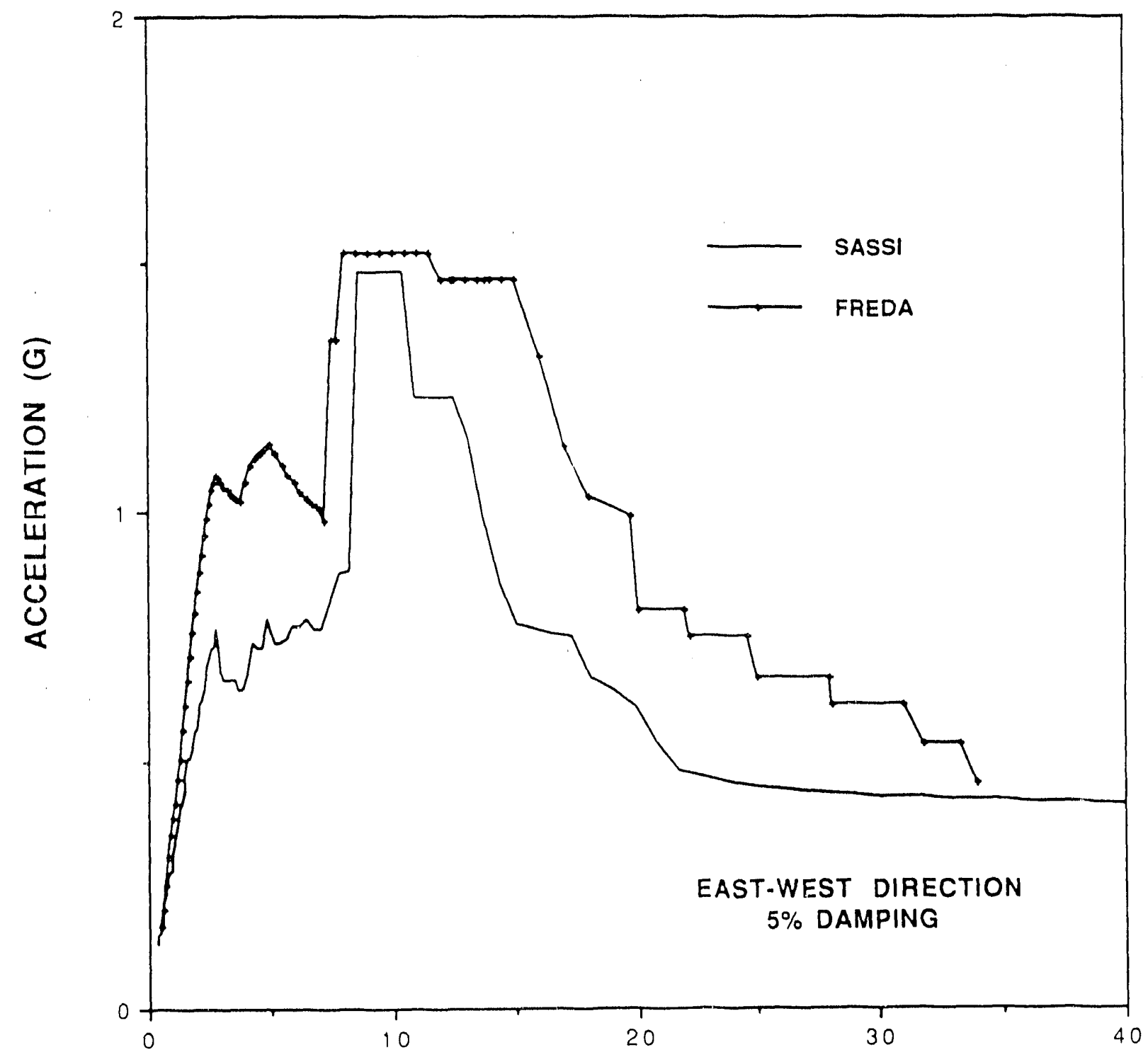

FREQUENCY (HZ)

FIGURE 18: COMPARISON OF FREDA FRS, AND SASSI FRS WITH NEW SOIL PROPERTIES FOR THE K-REACTOR, ELEVATION +130 FT. 
WESTINGHOLISE SAVANNAH RIVER (OMPAVY EQPI) SYSTEMS ENCIINEFIIVI;

SEISMIC STRUC'TURAL ENCIINEERIN(;

K.REACTOR SOIL PROFILE SILDY
IVSRR(・TR.1)1.t??

I:! $11 S I O S$

AUGUST, 1991

PAC FE F19 OF F31

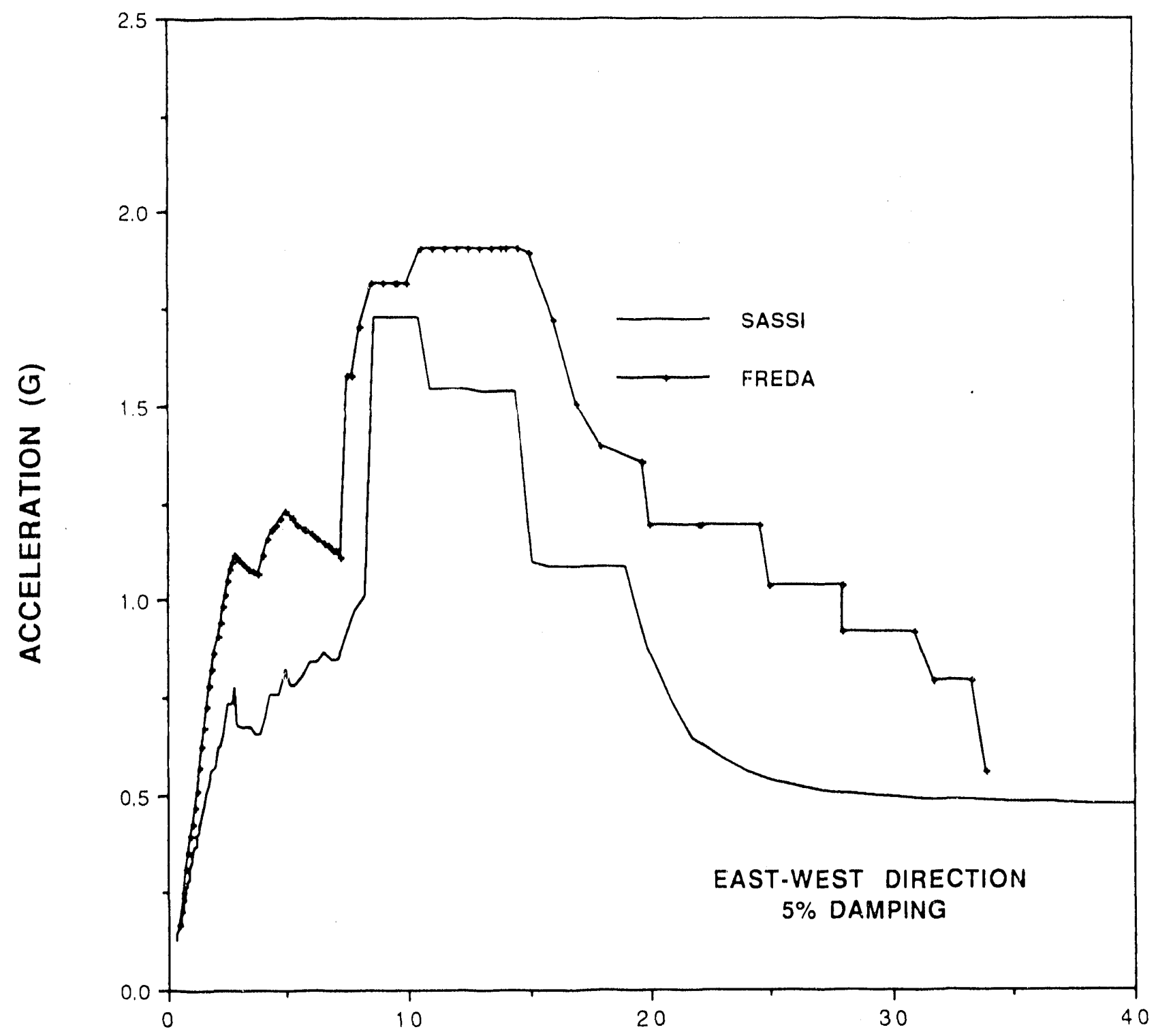

FREQUENCY (HZ)

FIGURE 19: COMPARISON OF FREDA FRS, AND SASSI FRS WITH NEW

SOIL PROPERTIES FOR THE K-REACTOR, ELEVATION +148.67 FT. 


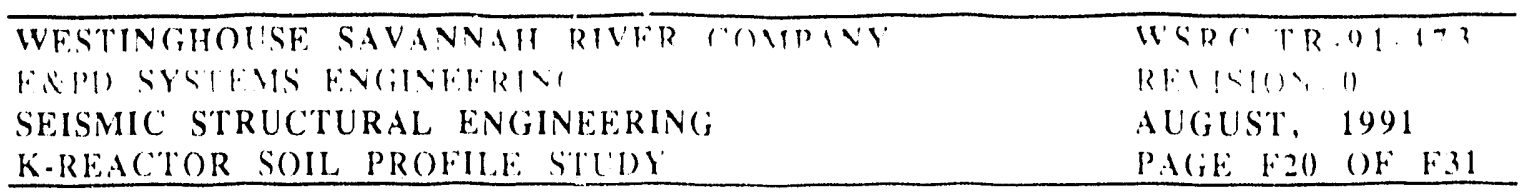

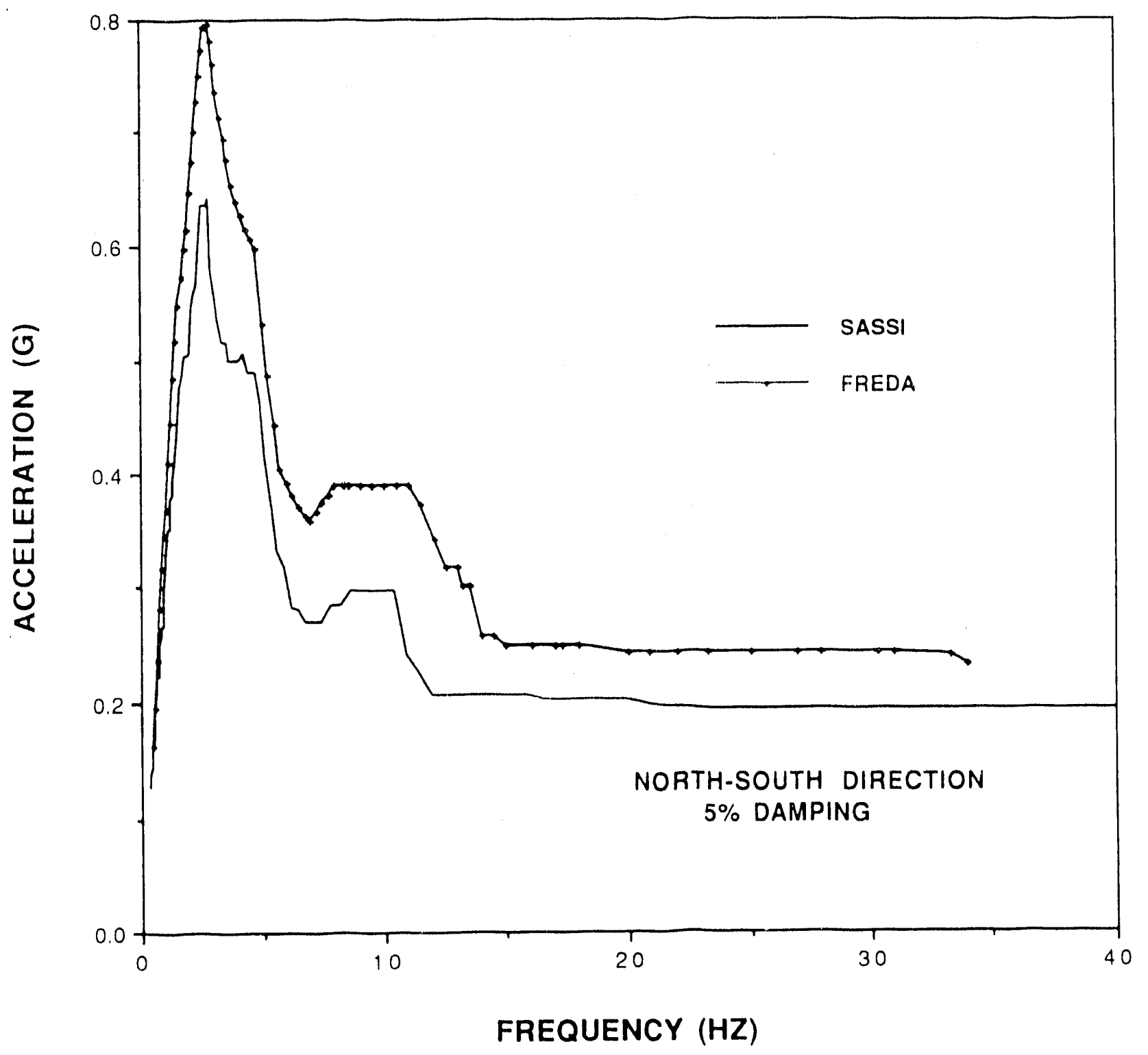

FIGURE 20: COMPARISON OF FREDA FRS, AND SASSI FRS WITH NEW SOIL PROPERTIES FOR THE K-REACTOR, ELEVATION -20 FT. 


\begin{tabular}{|c|c|}
\hline WESTIVGHOLCE SAVAVVIH & $T R \cdot 1) 1 \cdot 1+3$ \\
\hline 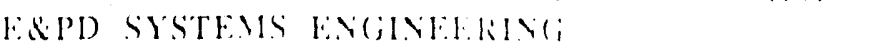 & KE:1510) 0 \\
\hline SEISMIC STRUCTURAL ENGINEERING; & AUciusl, 1991 \\
\hline K-REACTOR SOIL PROFILE SIID) & $P A(F F$ F21 (OF F31 \\
\hline
\end{tabular}

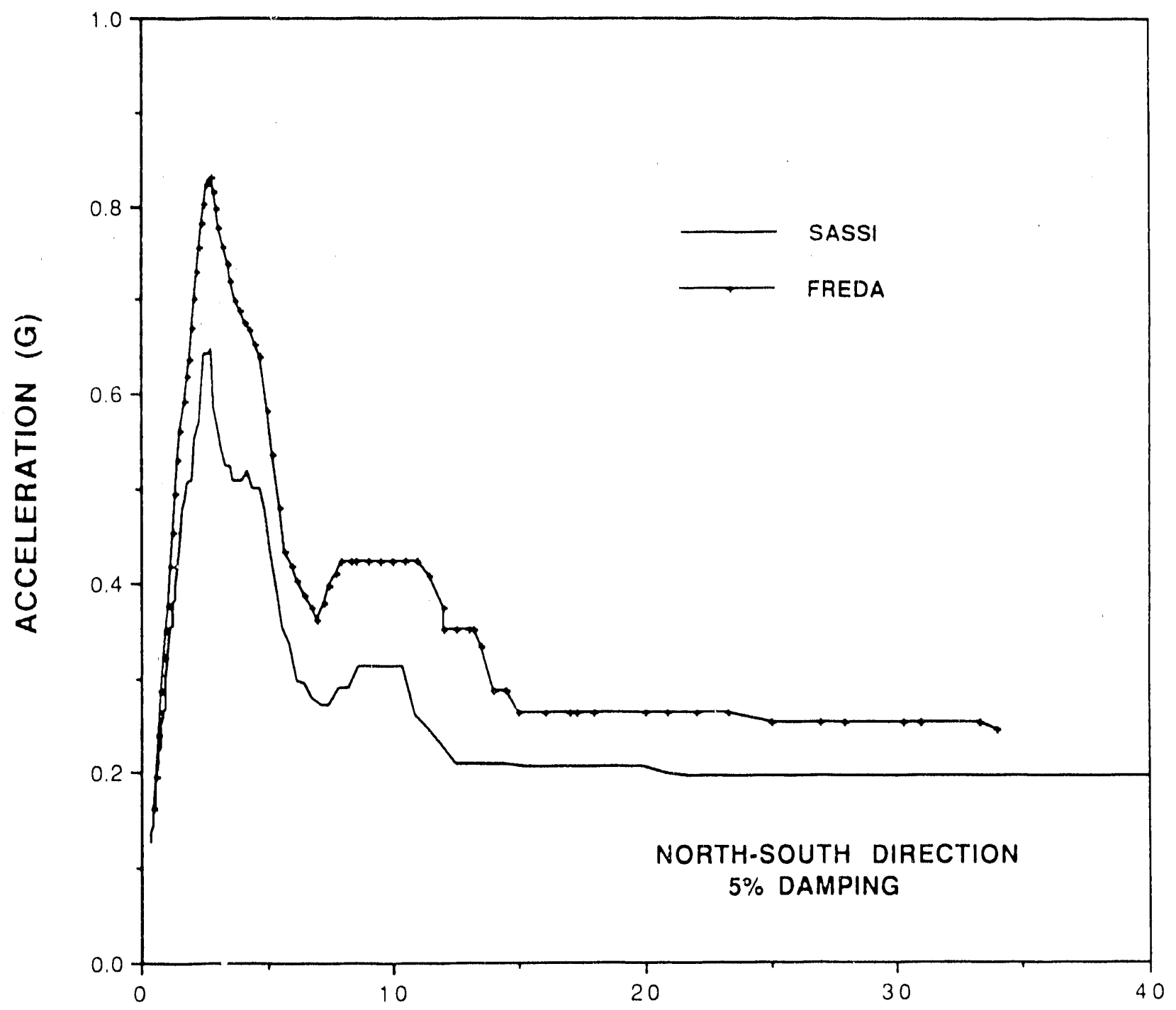

FREQUENCY (HZ)

FIGURE 21: COMPARISON OF FREDA FRS, AND SASSI FRS WITH NEW SOIL PROPERTIES FOR THE K-REACTOR, ELEVATION 0 FT. 


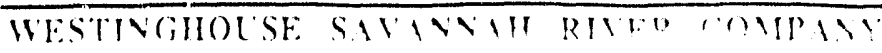

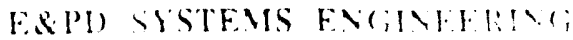

SEISMIC STRUCTURAL ENGINEERIN(;

K-RF.ACTOR SOIL PROFILL STIII)

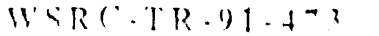

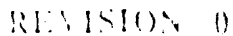

AUGUST, 1991

PACF, F22 OF F31

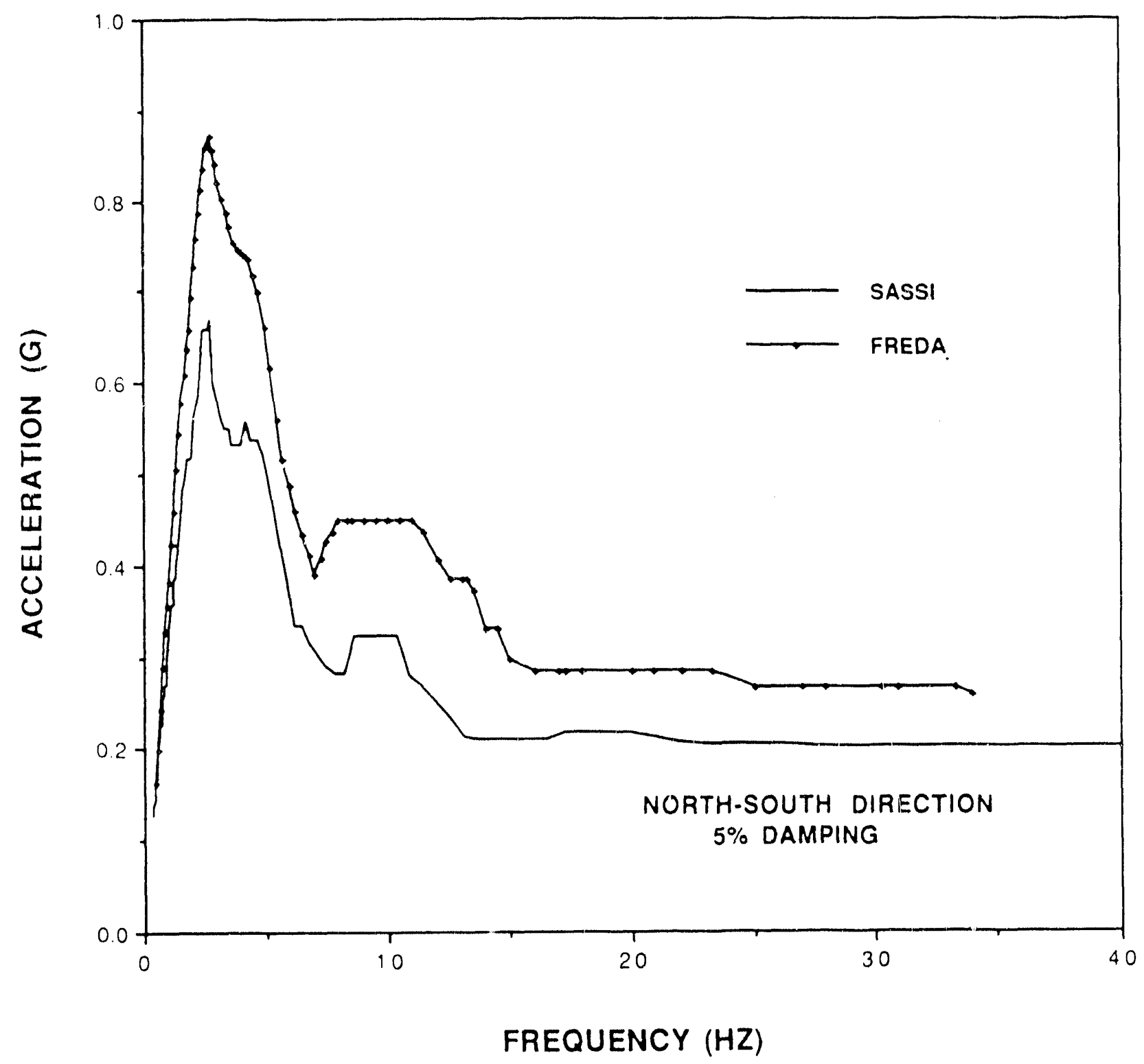

FIGURE 22: COMPARISON OF FREDA FRS, AND SASSI FRS WITH NEW SOIL PROPERTIES FOR THE K-REACTOR, ELEVATION + 15 FT. 
WESTINGHOUSE SAVANNAH RIVER (OMPANY

FAPD SYSTEMIS ENGINEERIU,

SEISMIC STRUC'TURAL ENGINEKRINC;

K-REACTOR SOIL PRONILE STIDY
IVSRC.TR.91.473

RFIISIOI 11

AUGUST, 1991

PAGE F 23 ()F F 31

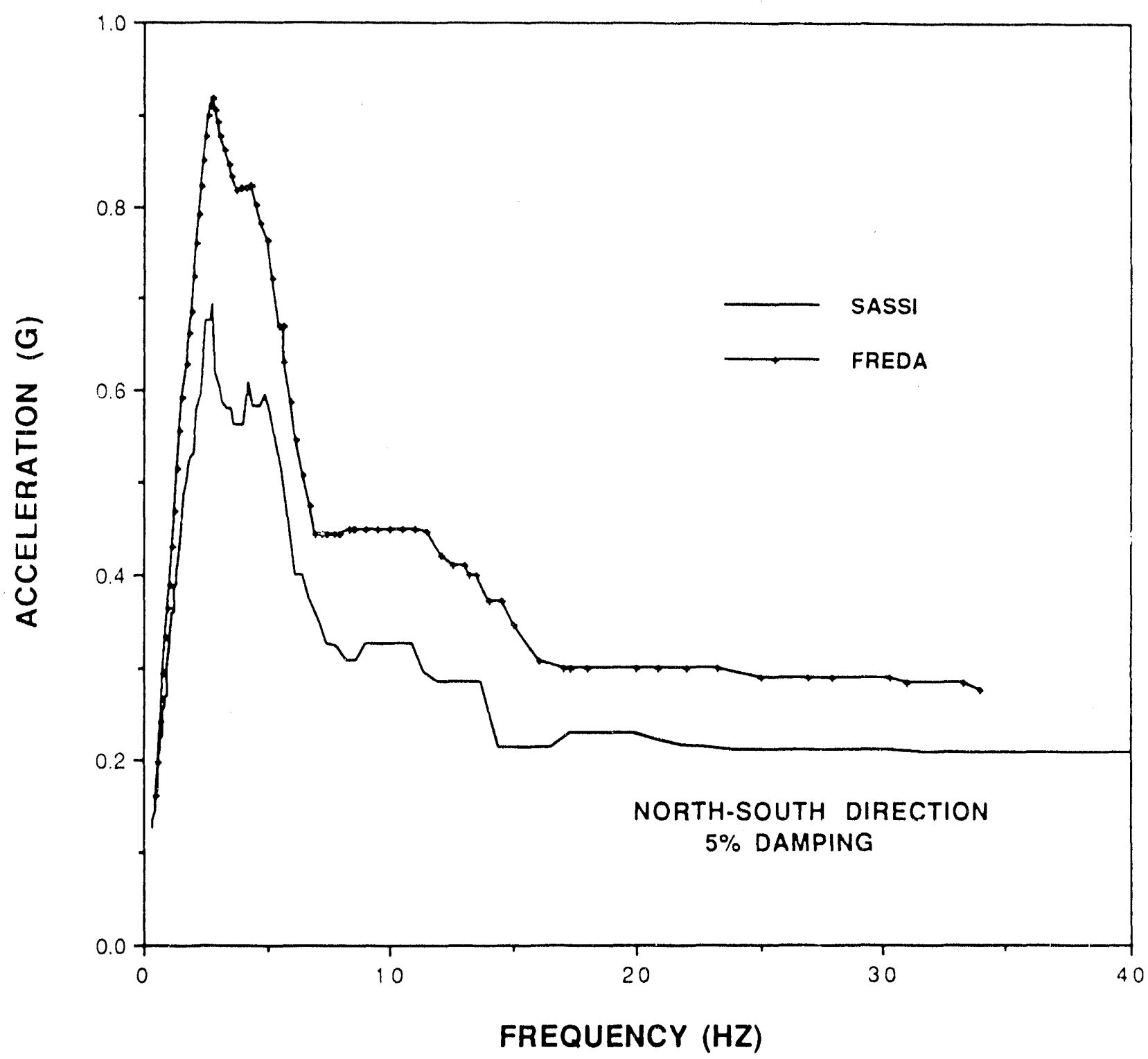

FIGURE 23: COMPARISON OF FREDA FRS, AND SASSI FRS WITH NEW SOIL PROPERTIES FOR THE K-REACTOR, ELEVATION + 34 FT. 


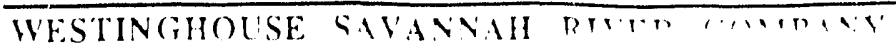
ESPD SISTEMS ENCINELRII, SEISMIC STRUCTURAL ENGINEERIN(; K.REACTOR SOIL PROFIIE STLITY
WSR (.TR-91-1-?

REILSION O

AUGUST, 1991

PAC FE FE ()F F3l

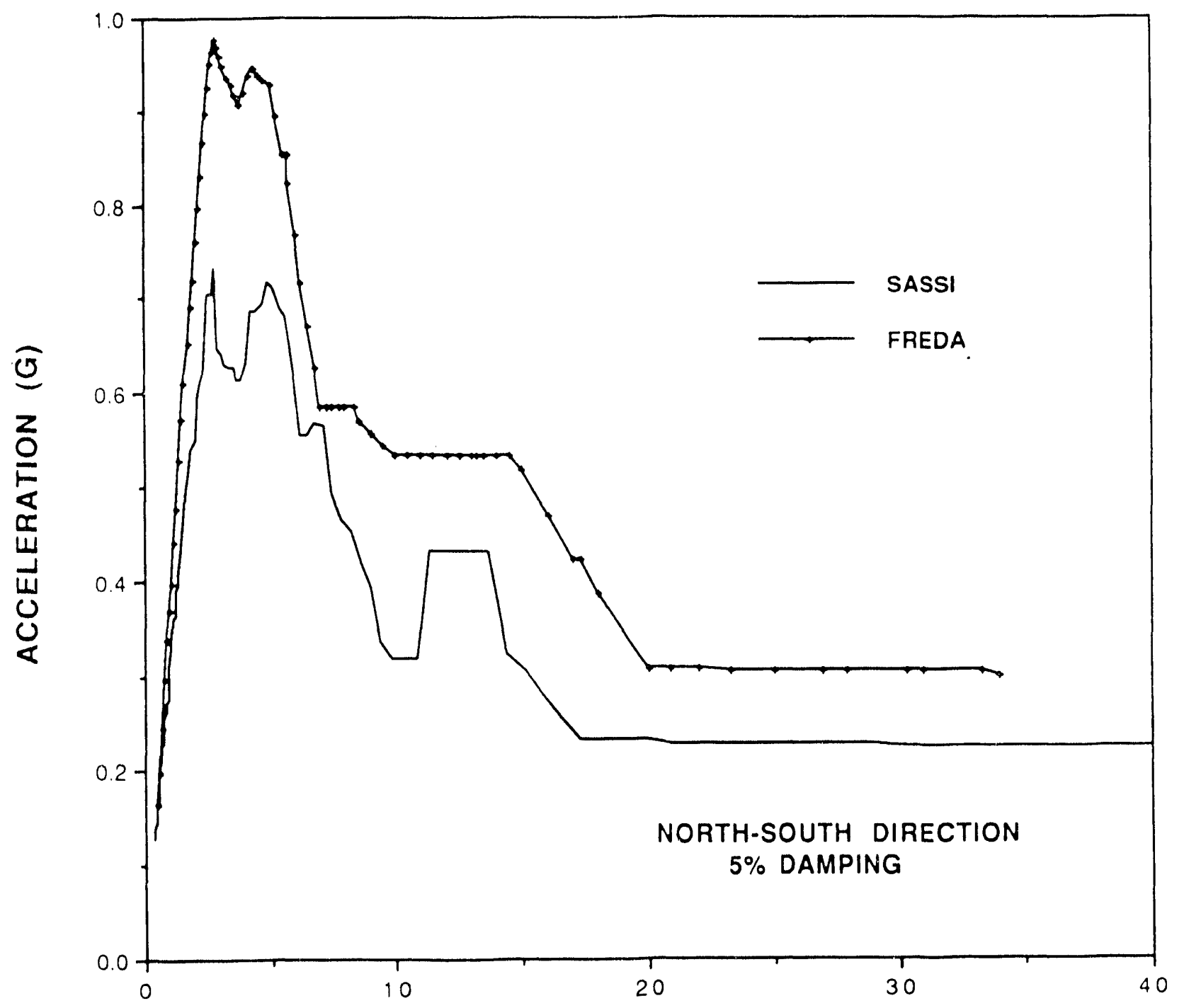

FREQUENCY $(\mathrm{HZ})$

FIGURE 24: COMPARISON OF FREDA FRS, AND SASSI FRS WITH NEW SOIL PROPERTIES FOR THE K-REACTOR, ELEVATION +48 FT. 


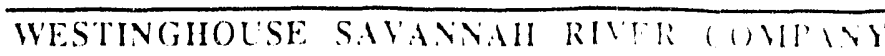
E\&PD SYSTFMS ENGINEERING;

SEISMIC STRUCTURAL ENGINEERIN(;

K.REACTOR SOIL PROFILE STEDY

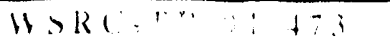

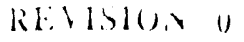
AUGUST, 1991 PACiE F25 ()F F31

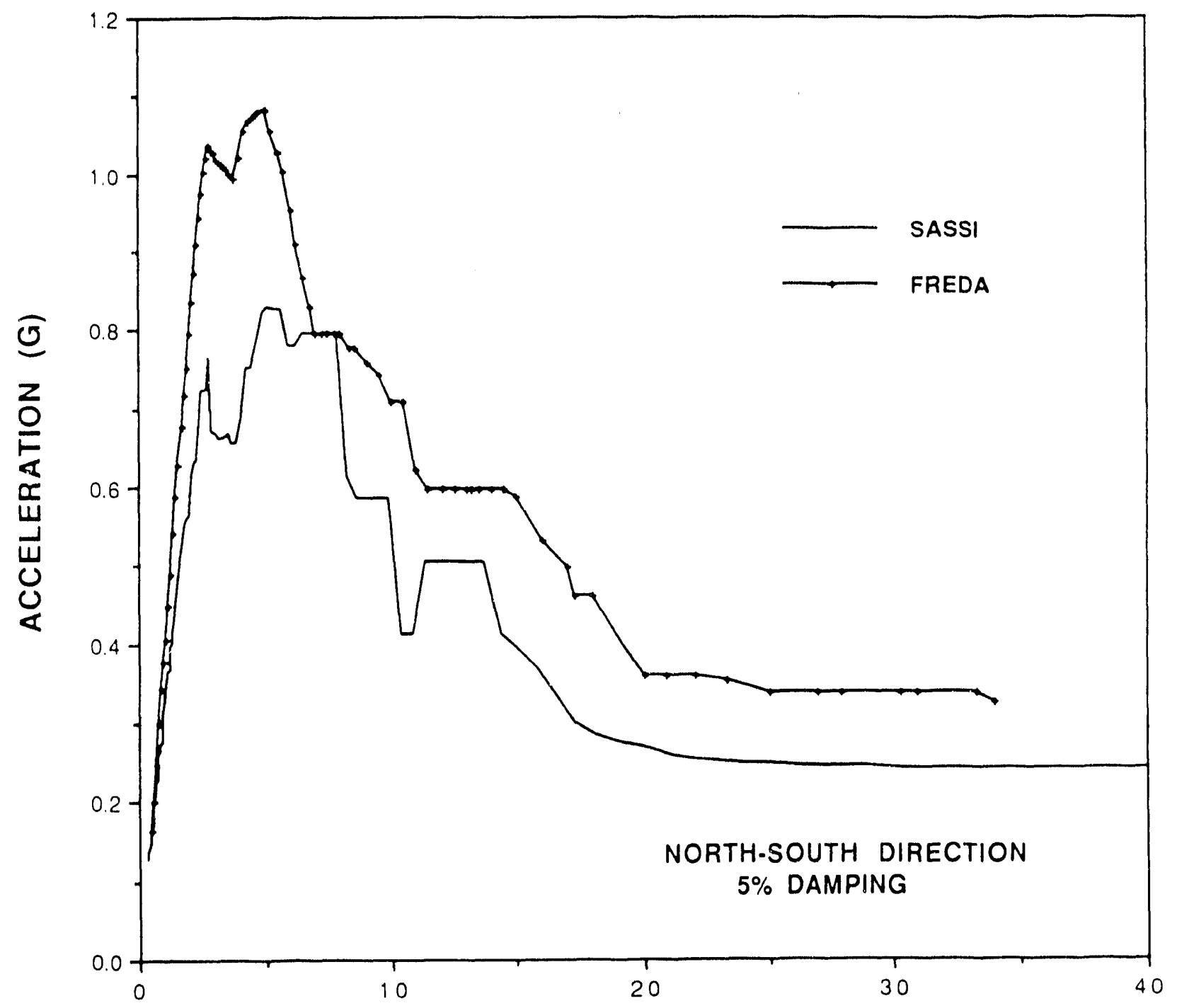

FREQUENCY (HZ)

FIGURE 25: COMPARISON OF FREDA FRS, AND SASSI FRS WITH NEW SOIL PROPERTIES FOR THE K-REACTOR, ELEVATION +66 FT. 


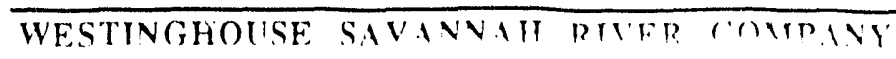

F\&PD "STI IS ENI:"

SEISMIC STRUCTURAL EN(;INEERINC;

K-REACTOR SOIL PROFILE STLDY
WSR (.TR-9) 1.+73

RELISION O

AUGUST, 1991

PAC FE F26 OF F31

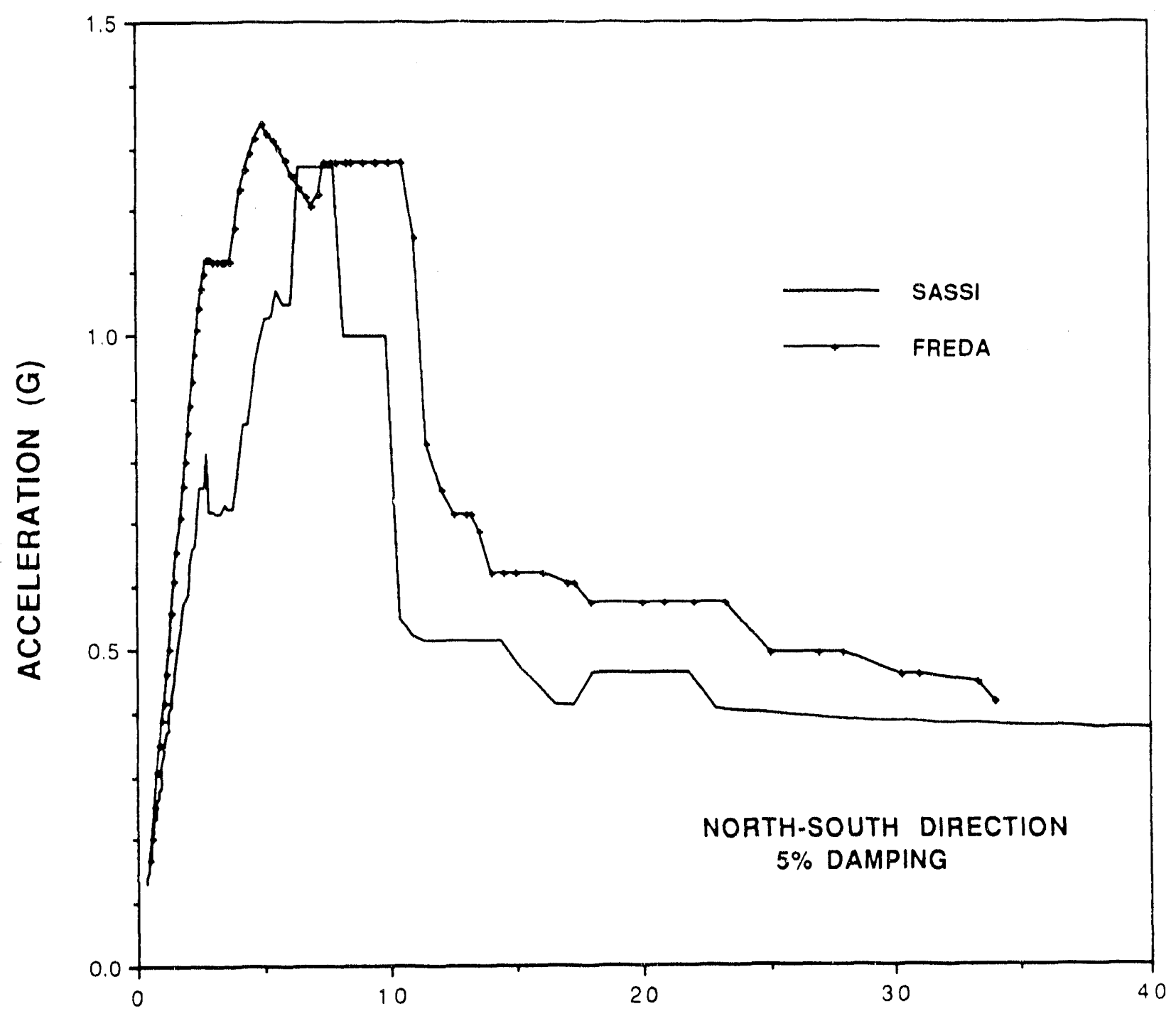

FREQUENCY (HZ)

FIGURE 26: COMPARISON OF FREDA FRS, AND SASSI FRS WITH NEW SOIL PROPERTIES FOR THE K-REACTOR, ELEVATION +91.25 FT. 
IVESTINGHOUSE SAVANNAH RIVFR I'OMPIVY' FRPD SYSTEMS ENGINEERING

SEISMIC STRUCTURAL ENGINEERIN(;

K.REACTOR SOIL PROFILE YTLDY
WSRC.TR.91. T73 REVISION 0

AUGUST, 1991 PACFE $\quad$ F27 OF $\quad$ H31

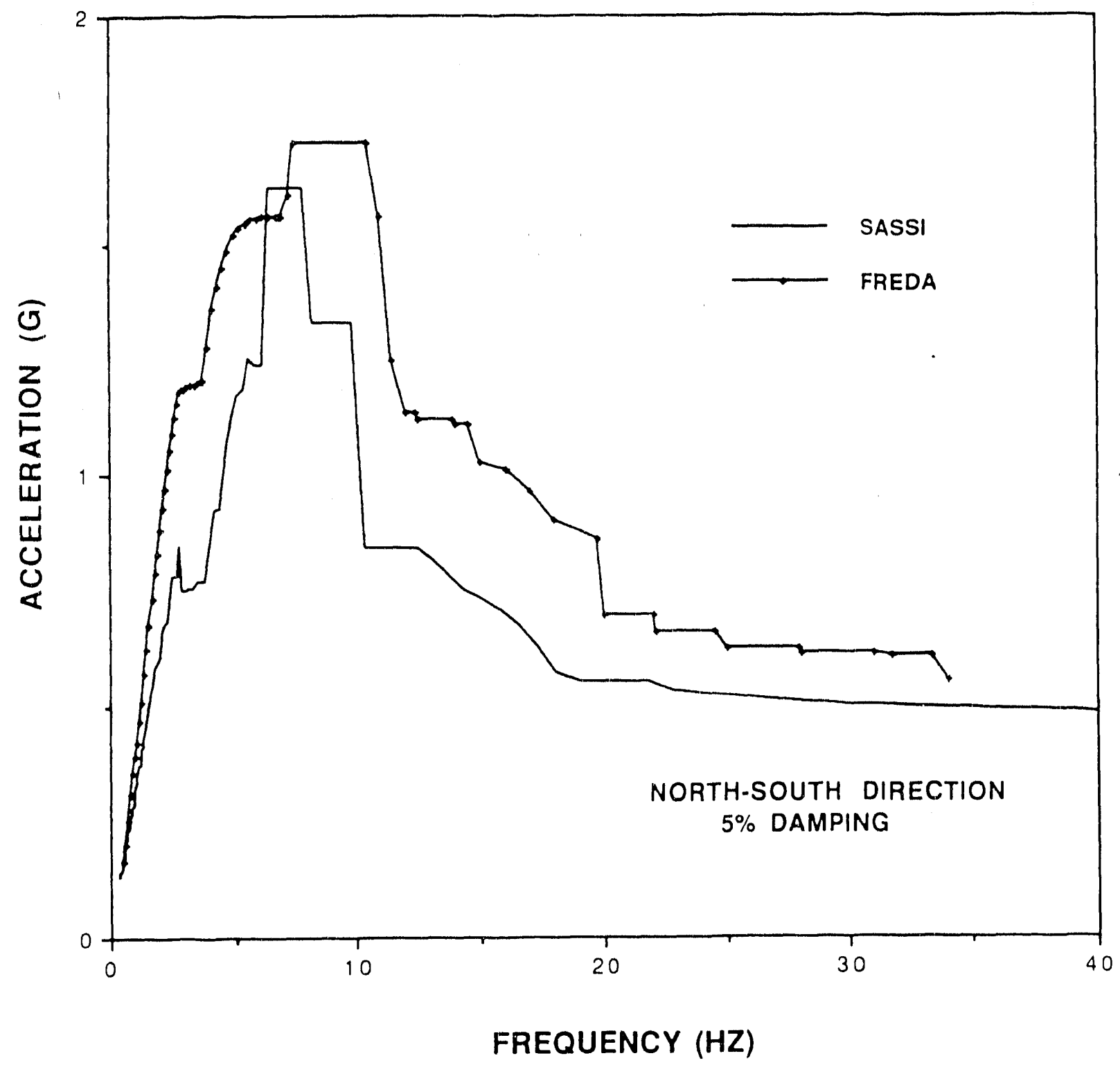

FIGURE 27: COMPARISON OF FREDA FRS, AND SASSI FRS WITH NEW SOIL PROPERTIES FOR THE K-REACTOR, ELEVATION + 110 FT. 
WESTINGHOIISF, SAVANNAH RIVER GOMPAVY

E\&PD SYSTEMS ENGINFERING;

SEISMIC STRUCTURAL ENGINEERING;

K-REACTOR SOIL PROFIIE STLDY
IVSR ( :TR - T $1 \cdot+7.3$

REIISION ()

AUGUST, 1991

PACE F28 OF F31

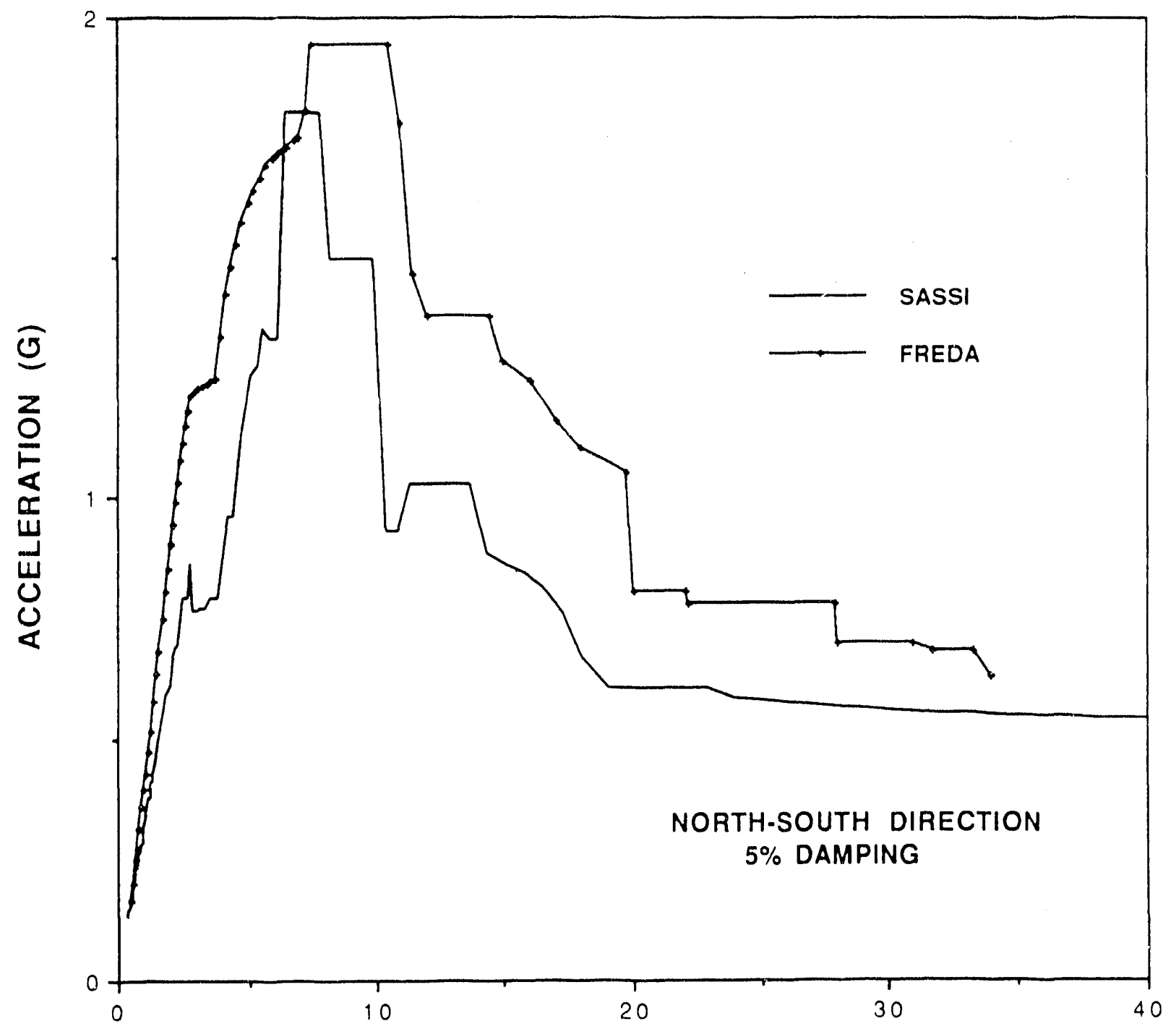

FREQUENCY (HZ)

FIGURE 28: COMPARISON OF FREDA FRS, AND SASSI FRS WITH NEW SOIL PROPERTIES FOR THE K-REACTOR, ELEVATION + 120 FT. 
WESTINGHOUSE SAVANNAH RIVER (OMPANY FEPD SYSTEMS ENGINEFRING; SEISMIC STRUCTURAL ENGINEERIN(; K.REACTOR SOIL, PROFIIE STI'DY'
WSR $(\cdot T R \cdot 91 \cdot+7.3$ REVISION ()

AUiusl, 1991 PACE F29 OF F31

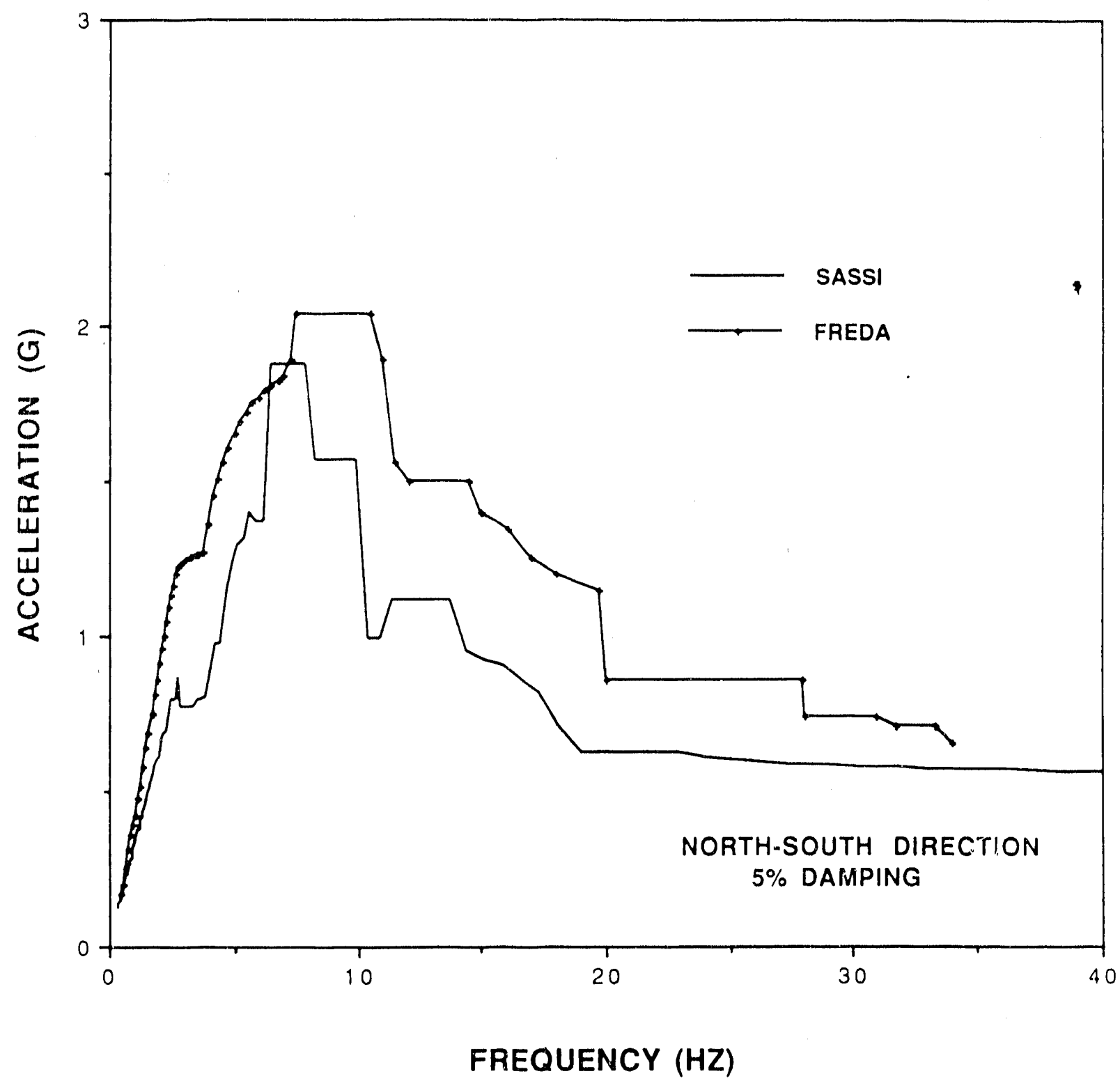

FIGURE 29: COMPARISON OF FREDA FRS, AND SASSI FRS WITH NEW SOIL PROPERTIES FOR THE K-REACTOR, ELEVATION + 125 FT. 
WESTINGIOUSE SAVAVNAII RIVER (OMMANY FAPD SYSTEMS ENGINFERIVI;

SEISMIC STRUCTURAL EN(INAERIN(;

K-REACTOR SOIL PROFILE TIUDY
WSRC.TR-91-173

REISSIO)

AUGUS', 1991

PA(iE F30 OF F31

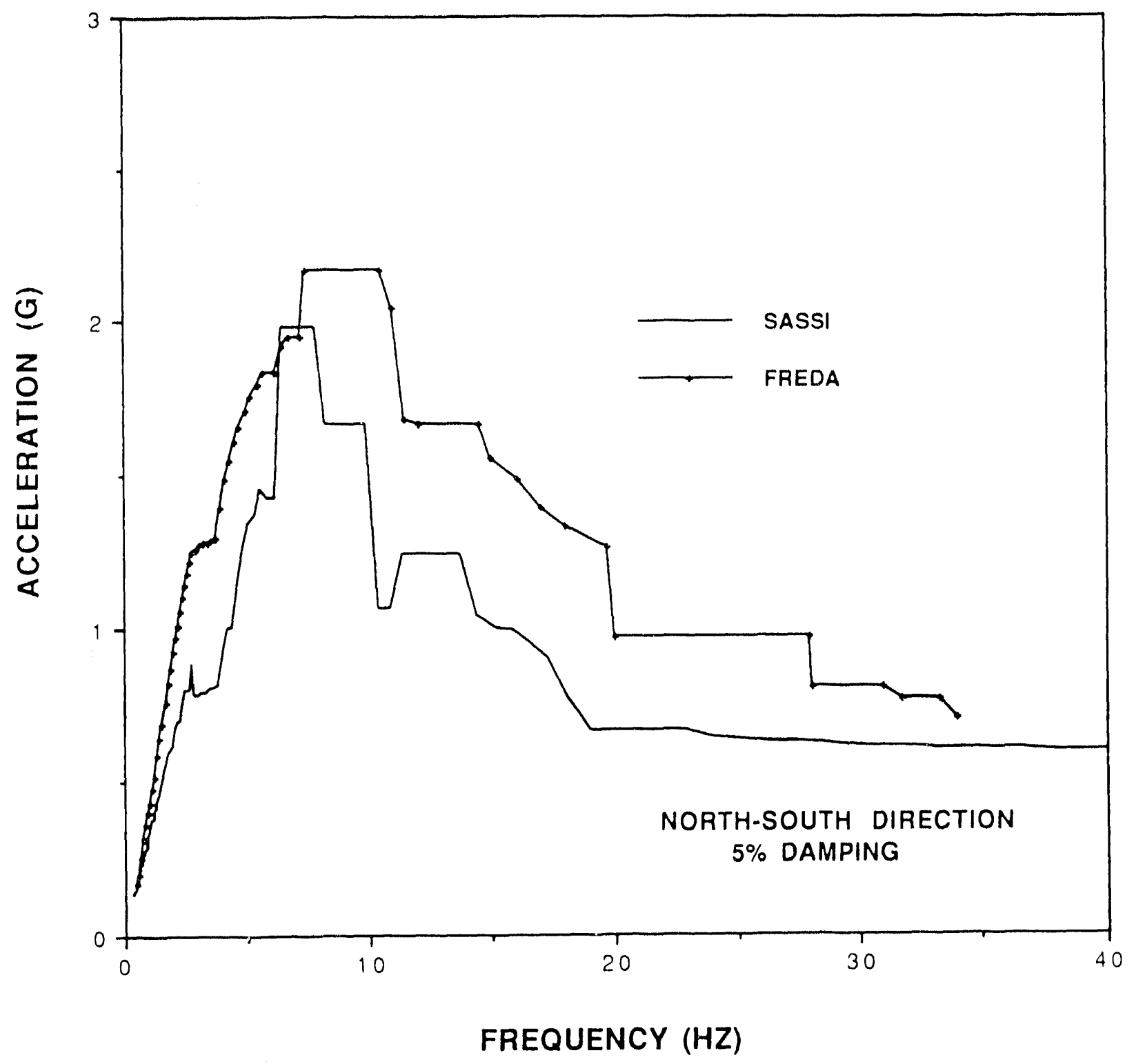

FIGURE 30: COMPARISON OF FREDA FRS, AND SASSI FRS WITH NEW SOIL PROPERTIES FOR THE K-REACTOR, ELEVATION +130 FT. 
WESTINGHOUSE SAVANNAH RIVER COMPANY ESPD SYSTHUS FUIINGKKIUT.

SEISMIC STRUCIURAL ENGINEERING;

K-REACTOR SOIL PROFILE STUDY
WSR $(\cdot T R \cdot 91 \cdot+7.3$

REVISION ()

AUGUST, 1991

PAliF F31 OF F31

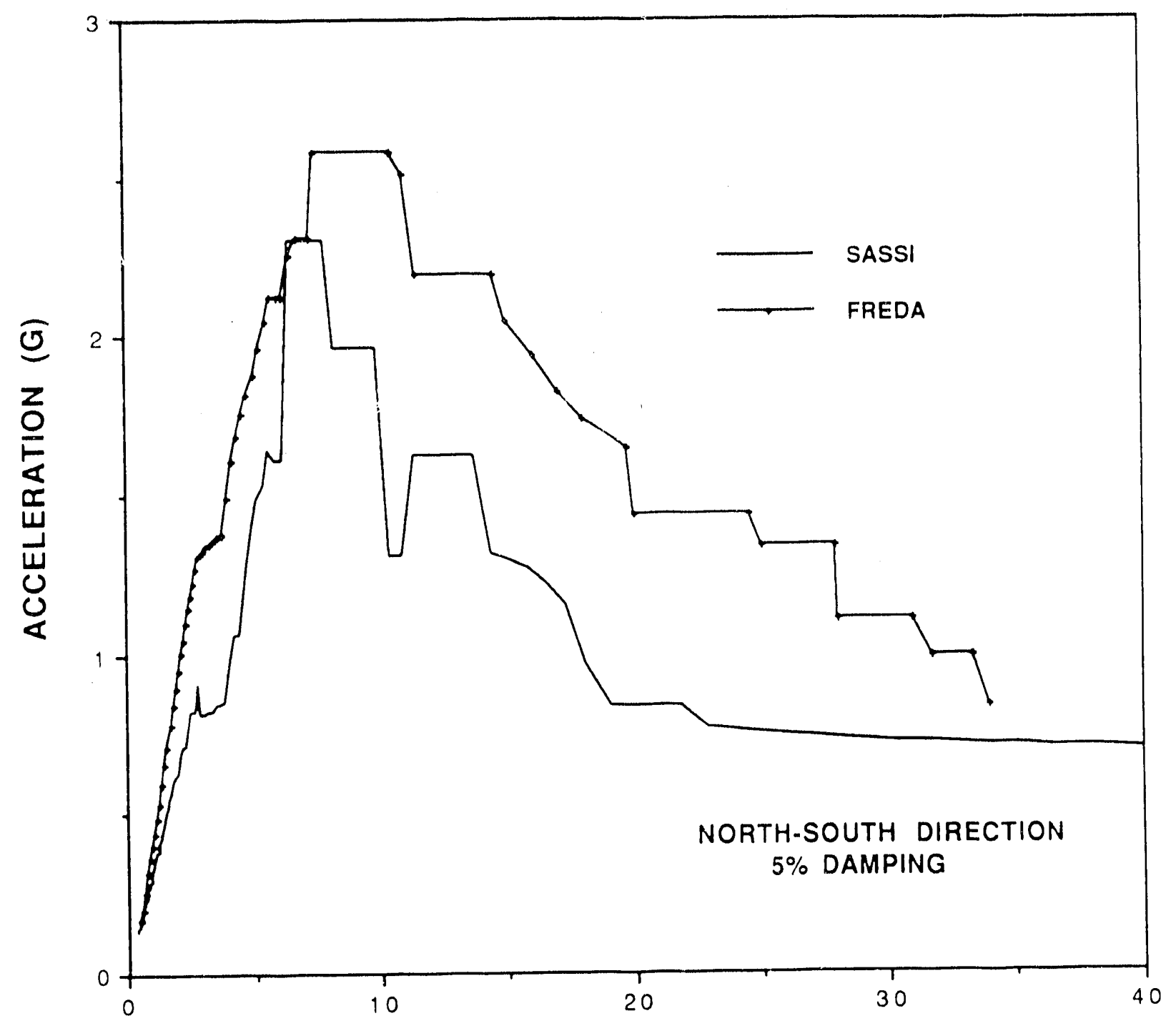

FREQUENCY (HZ)

FIGURE 31: COMPARISON OF FREDA FRS, AND SASSI FRS WITH NEW SOIL PROPERTIES FOR THE K-REACTOR, ELEVATION + 148.67 FT. 

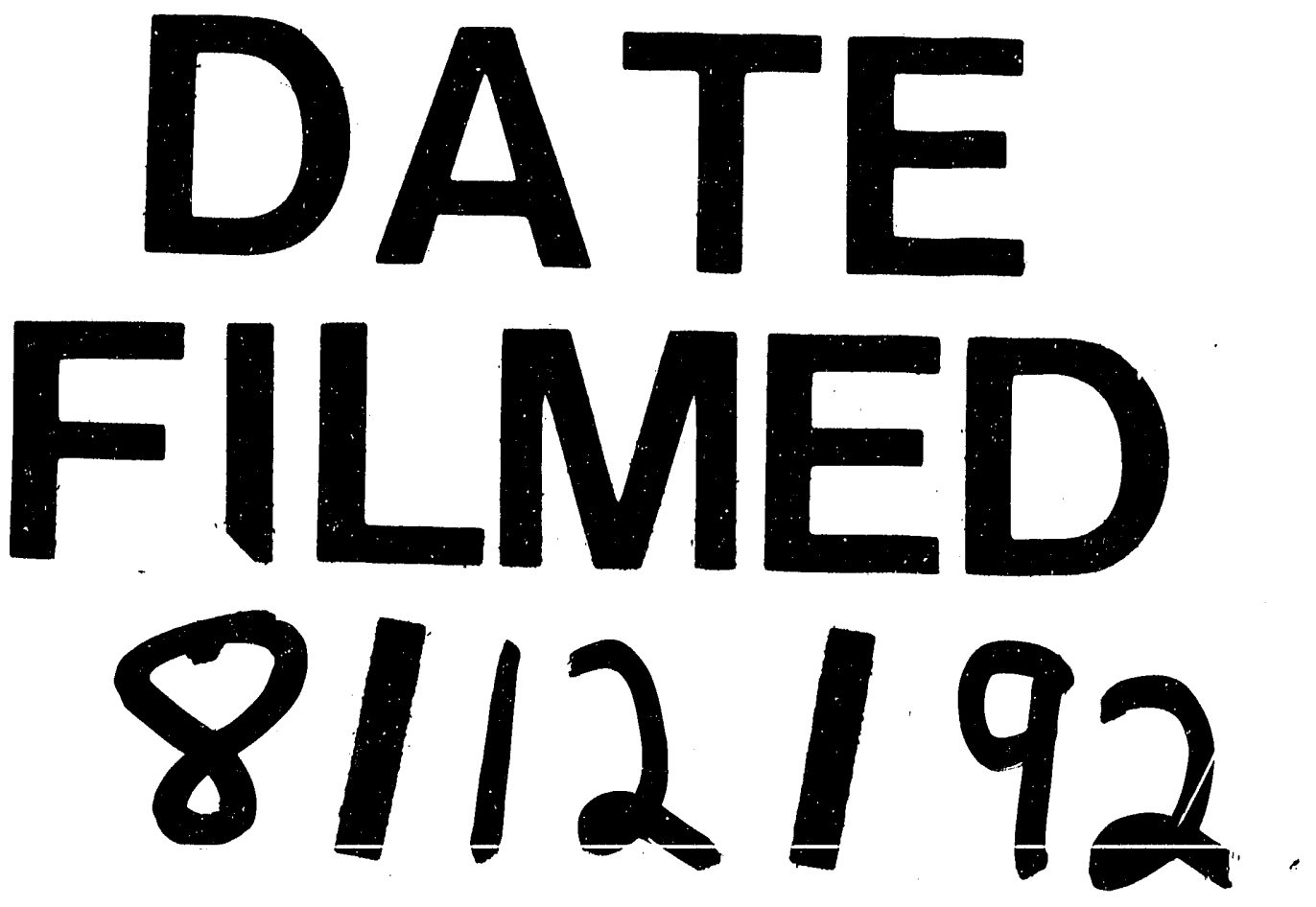
